"This is an Accepted Manuscript of an article published by Taylor \& Francis in Archives of Physiology and Biochemistry on 2017, available online:

http://www.tandfonline.com/doi/abs/." 


\section{IL-1 $\beta$ and TNF $\alpha$ inhibit GPR120 (FFAR4) and stimulate GPR84 (EX33) and GPR41 (FFAR3) fatty acid receptor expression in human adipocytes: implications for the anti-inflammatory action of $n-3$ fatty acids}

Laura Muredda ${ }^{1}$, Małgorzata A. Kępczyńska ${ }^{1}$, Mohamed S. Zaibi1ª, Suliman Y. Alomar ${ }^{2}$, Paul Trayhurn ${ }^{1,2,3}$

${ }^{a}$ Clore Laboratory, University of Buckingham, Buckingham, United Kingdom, ${ }^{2}$ Zoology Department, College of Science, King Saud University, Riyadh, Saudi Arabia, and 'Bbesity Biology Unit, University of Liverpool, Liverpool, United Kingdom

RUNNING TITLE: GPR fatty acid receptor gene expression

Keywords: Adipose tissue, docosahexaenoic acid, fatty acid sensors, inflammation

*Correspondence should be addressed to:

Professor Paul Trayhurn, FRSE

Clore Laboratory

University of Buckingham

Hunter Street

Buckingham MK18 1EG, UK

Email: p.trayhurn@liverpool.ac.uk

Fax: $\quad+441280820135$ 


\begin{abstract}
Regulation of the expression of GPCR fatty acid receptor genes has been examined in human adipocytes differentiated in culture. TNF $\alpha$ and IL-1 $\beta$ induced a marked reduction in GPR120 expression, mRNA level falling 17 -fold at $24 \mathrm{~h}$ in adipocytes incubated with TNF $\alpha$. In contrast, GPR84 mRNA was dramatically increased by these cytokines ( $>500$-fold for IL-1 $\beta$ at $4 \mathrm{~h}$ ); GPR41 expression was also stimulated. Rosiglitazone did not affect GPR84 expression, but GPR120 and GPR41 expression increased. Dexamethasone, insulin, linoleic and docosahexaenoic acids, and TUG891 (GPR120 agonist) had little effect on GPR120 and GPR84 expression. TUG891 did not attenuate the pro-inflammatory actions of TNF $\alpha$ and IL-1 $\beta$. Docosahexaenoic acid slightly countered the actions of IL-1 $\beta$ on CCL2, IL6 and ADIPOQ expression, though not on secretion of these adipokines. GPR120 and GP84 gene expression in human adipocytes is highly sensitive to pro-inflammatory mediators; the inflammation-induced inhibition of GPR120 expression may compromise the anti-inflammatory action of GPR120 agonists.
\end{abstract}




\section{Introduction}

Several members of the extended family of G-protein-coupled receptors (GPCR) are specific sensors/receptors for fatty acids, each of which is selective for different types of fatty acid. GPR40 (also known as FFAR1) is activated by saturated and unsaturated medium and long chain fatty acids (C8-C22) with GPR41 (FFAR3) and GPR43 (FFAR2) being receptors for short chain fatty acids (C1-C6) (Milligan et al., 2014; Watterson et al., 2014; Ulven \& Christiansen, 2015). GPR84 (EX33) is activated primarily by medium chain fatty acids (C9 to C14 are the most potent), while GPR120 (FFAR4) is considered as a receptor for $n$-3 polyunsaturated fatty acids (PUFA), although it is also activated by medium and long chain fatty acids (Oh et al., 2010; Milligan et al., 2014; Watterson et al., 2014). These GPCRs have been linked to a range of metabolic effects, activation of GPR40, for example, leading to the stimulation of glucosedependent insulin secretion by pancreatic $\beta$ cells (Itoh et al., 2003), while activation of GPR43 by short chain fatty acids stimulates the release of leptin from adipocytes and of GLP-1 from colonic cells (Zaibi et al., 2010; Tolhurst et al., 2012).

GPR84, which is the least studied of the GPCR fatty acid sensors, is reported to be a proinflammatory receptor, activation by medium chain fatty acids resulting in chemotaxis and cytokine production by macrophages (Suzuki et al., 2013). Activation of GPR120 by n-3 PUFA, on the other hand, has been linked to the insulin-sensitising and anti-inflammatory actions of these fatty acids, particularly in relation to obesity (Oh et al., 2010; Oh \& Olefsky, 2012; Ulven \& Christiansen, 2015; Moniri, 2016). GPR120 knockout mice become obese on a high fat diet and exhibit multiple metabolic disorders, including insulin resistance associated with reduced insulin signalling and enhanced inflammation in white adipose tissue (Ichimura et al., 2012). Other functions attributed to GPR120 in adipose tissue include the promotion of adipogenesis (Song et al., 2016) and the stimulation of VEGF-A production by mature adipocytes (Hasan et al., 2015).

Each of the GPCRs for fatty acids exhibit selective tissue and cellular distribution in their expression. The GPR120 gene is widely expressed, but expression is particularly evident in adipose tissue, both in adipocytes themselves and in M1 and M2 macrophages (Oh et al., 2010). GPR84 is also expressed in adipocytes, as well as in leukocytes and other immune cells (Wang et al., 2006; Nagasaki et al., 2012). GPR84 expression in monocytes/macrophages has been shown to be markedly induced by lipopolysaccharide (Wang et al., 2006), while in adipocytes both macrophage secretions and TNF $\alpha$ stimulate expression (Nagasaki et al., 2012; Trayhurn \& Denyer, 2012). In contrast, macrophage secretions appear to down-regulate GPR120 expression (Trayhurn \& Denyer, 2012). These observations suggest that GPR84 and GPR120 are intimately connected to the inflammatory response in adipose tissue which is evident in obesity, the obese 
state being characterised by chronic inflammation in the tissue (Rajala \& Scherer, 2003; Trayhurn \& Wood, 2004; Hotamisligil, 2006). Adipose tissue inflammation is widely considered to underlie the development of several obesity-associated disorders, particularly insulin resistance and the metabolic syndrome (Hotamisligil, 2006; Rosen \& Spiegelman, 2006; Bluher, 2009).

The aim of the present study was: (i) to examine the regulation of GPR120 and GPR84 expression in human adipocytes by a range of factors, both pro-inflammatory and antiinflammatory, and including GPR120 agonists; (ii) to examine the effect of GPR120 agonists, synthetic and natural, on the inflammatory response induced by TNF $\alpha$ and IL-1 $\beta$ in human fat cells. The results demonstrate that both TNF $\alpha$ and IL-1 $\beta$ markedly stimulate the expression of GPR84, but inhibit GPR120 expression, and that agonists to GPR120 have little or no effect on the stimulation of inflammation by these cytokines in human adipocytes.

\section{Materials and methods}

\section{Adipocyte cell culture}

Human fibroblastic pre-adipocytes were purchased from PromoCell (Germany; Catalogue \#C12730, Lots \#400Z008.1 and 404Z027.2), together with proprietary cell culture media. The preadipocytes were isolated from the subcutaneous adipose tissue of Caucasian females (aged 29 and 46 years). As previously described, the pre-adipocytes were plated into 12 -well plates $(5,000$ cells $/ \mathrm{cm}^{2}$ ), cultured to confluence, differentiated into adipocytes and then further cultured for up to 14 days (Alomar et al., 2015). In outline, the pre-adipocytes were first cultured in a growth medium containing $5 \%$ foetal calf serum, epidermal growth factor $(10 \mathrm{ng} / \mathrm{ml})$, hydrocortisone (1 $\mu \mathrm{g} / \mathrm{ml}$ ) and heparin $(90 \mu \mathrm{g} / \mathrm{ml})$. They were then transferred to a differentiation medium (without foetal calf serum) for $72 \mathrm{~h}$, this medium containing IBMX (44 $\mu \mathrm{g} / \mathrm{ml})$, thyroxine $(9 \mathrm{ng} / \mathrm{ml})$, dexamethasone $(400 \mathrm{ng} / \mathrm{ml})$, insulin $(0.5 \mu \mathrm{g} / \mathrm{ml})$ and the PPAR $\gamma$ agonist rosiglitazone $(3 \mu \mathrm{g} / \mathrm{ml})$. The differentiating cells were finally incubated in a nutrition medium which contained 3\% foetal calf serum, dexamethasone $(400 \mathrm{ng} / \mathrm{ml})$ and insulin $(0.5 \mu \mathrm{g} / \mathrm{ml})$; this growth medium was changed every 2-3 days. The differentiated adipocytes were used at between 12 and 14 days after differentiation was induced, by which time they contained multiple lipid droplets.

To assess the effects on GPCR gene expression, the fat cells were incubated for either 4 or $24 \mathrm{~h}$ with one of the following agents: human recombinant IL-1 $\beta$ ( 0.5 or $2 \mathrm{ng} / \mathrm{ml}$ : Sigma, UK), $\mathrm{TNF} \alpha(5$ and $100 \mathrm{ng} / \mathrm{ml}$; Sigma, UK), rosiglitazone (0.1 and $1 \mu \mathrm{M}$; Sigma, UK), dexamethasone (2 and 20 nM; Sigma, UK ), insulin (1 and 20 nM; Sigma, UK) or TUG891 (0.5 and $10 \mu \mathrm{M}$; University of Southern Denmark, Denmark). Control cells received vehicle. In studies investigating the effects of insulin and dexamethasone, these hormones were removed from the 
culture medium $24 \mathrm{~h}$ before the start of the experiment (and were absent from the control cells). For experiments with the fatty acids linoleic acid and docosahexaenoic acid (DHA), two concentrations were used; 25 and $100 \mu \mathrm{M}$ for DHA, and 50 and $200 \mu \mathrm{M}$ for linoleic acid. The fatty acids were added to the nutrition medium which was supplemented with $0.3 \%$ bovine serum albumin.

At the end of the incubation period, the culture medium was aspirated and stored at $-20^{\circ} \mathrm{C}$; the adipocytes were washed and frozen in TRI Reagent (Sigma, UK) and stored at $-80^{\circ} \mathrm{C}$. A total of 3-6 individual sets of cells was taken for each experimental group.

\section{RNA extraction and real-time PCR}

The adipocytes were thawed on ice, homogenised in the TRI Reagent in which they had been stored and total RNA extracted using an RNeasy Micro Kit (Qiagen, UK). The purity of the RNA was close to 2.0, based on the 260/280 $\mathrm{nm}$ and 260/230 $\mathrm{nm}$ ratios (NanoDrop 1000; Wilmington, USA). The RNA Integrity Number (Agilent 2100 Bioanalyser; Agilent Technologies, Germany) was approximately 10 .

The total RNA was DNAse-treated with a TURBO-DNA-free ${ }^{\mathrm{TM}}$ kit (Ambion, Life Technologies $^{\mathrm{TM}}$, USA) and 0.8-1.6 $\mu \mathrm{g}$ was reverse transcribed using Taqman $^{\circledR}$ reverse transcription reagents (Invitrogen ${ }^{\mathrm{TM}}$, Applied Biosystems, UK). Between 60 and $80 \mathrm{ng}$ of cDNA was taken for real-time PCR which was performed in triplicates using Gene Expression Master Mix and TaqMan ${ }^{\circledR}$ Gene Assays consisting of specific Taqman ${ }^{\circledR}$ probes (Applied Biosystems ${ }^{\circledR}$, Life Technologies" ${ }^{\mathrm{TM}}$, USA). Probes were obtained for the human GPR40 (Hs03045166_s1), GPR41 (Hs02519193_g1), GPR43 (Hs00271142_s1), GPR84 (Hs01874713_s1), GPR120 (Hs00699184_m1), CCL2 (Hs00234140_m1), IL1B (Hs01555410_m1), IL6 (Hs00985639_m1), IL16 (Hs00189606_m1) and ADIPOQ (Hs00605917_m1) genes; probes were also obtained for ACTB ( $\beta$-actin; Hs99999903_m1) as the control gene. PCR reactions were set up in duplex format where the FAM-labelled Taqman ${ }^{\circledR}$ probe for the gene of interest was mixed with the VIClabelled Taqman ${ }^{\circledR}$ probe for $A C T B$.

PCR amplification was performed using an ABI real-time PCR detection system (ABI StepOneplus ${ }^{\mathrm{TM}}$, Applied Biosystems ${ }^{\circledR}$, USA) with a two-step thermal cycling: $95^{\circ} \mathrm{C}$ for $10 \mathrm{~min}$, followed by 40 cycles of $95^{\circ} \mathrm{C}$ for $15 \mathrm{sec}$ and $60^{\circ} \mathrm{C}$ for $1 \mathrm{~min}$. The data were analysed by the comparative $2^{-\Delta \Delta} \mathrm{Ct}$ method (Livak \& Schmittgen, 2001) and expressed as fold-changes in the target gene (normalized to $A C T B$ as the reference gene) in treated adipocytes and related to the expression of the control adipocytes (normalised to the mRNA level in the control cells $=1.0$ ). 


\section{PCR atrays}

PCR arrays were performed essentially according to the manufacturer's instructions, as described previously (Alomar et al., 2015; Kepczynska et al., 2017). Extracted RNA was DNAse-treated, reverse transcribed using a $\mathrm{RT}^{2}$ First Strand Kit (Qiagen, UK) and then screened with a $\mathrm{RT}^{2}$ Profiler PCR array for 84 Human Cytokine and Chemokine genes (Qiagen; Catalogue \#PAHS150ZC-24). PCR amplification was performed by real-time PCR (ABI StepOneplus) with twostep thermal cycling using the following protocol; $95^{\circ} \mathrm{C}$ for $10 \mathrm{~min}$, and then 40 cycles of $95^{\circ} \mathrm{C}$ for $15 \mathrm{sec}$ and $60^{\circ} \mathrm{C}$ for $1 \mathrm{~min}$. The data were analysed by the comparative $2^{-\Delta \Delta} \mathrm{Ct}$ method (Livak $\&$ Schmittgen, 2001) and expressed as fold-changes in the target gene normalised to the reference genes ( $A C T B, B 2 M, G A P D H, H P R T, R L P O)$ for the adipocytes treated with TNF $\alpha$ and related to the expression level in the control cells.

\section{Protein measurements}

The concentration of the adipokines IL-6, IL-16, MCP-1 (encoded by CCL2) and adiponectin was measured in the medium using MSD immunoassays (Meso Scale Discovery, USA); these assays enable the rapid and sensitive measurement of specific proteins in small sample volumes. Before analysis, the media were centrifuged to remove any cell debris. Plates were pre-coated with antibodies on independent, discrete spots and the assay then performed essentially according to the manufacturer's instructions, as described previously (Alomar et al., 2015; Alomar et al., 2016). The data was analysed using Proprietary Meso Scale software. The lowest level of detection was $0.06 \mathrm{pg} / \mathrm{ml}$ for IL-6 (interlot CV $<20 \%$ ), $2.83 \mathrm{pg} / \mathrm{ml}$ for IL-16 (interlot CV <20 $\%$ ), $0.09 \mathrm{pg} / \mathrm{ml}$ for MCP-1 and $5 \mathrm{pg} / \mathrm{ml}$ for adiponectin (mean intraplate $\mathrm{CV}<20 \%$ for MCP-1 and adiponectin).

\section{Statistical analysis}

The statistical significance of differences between groups was assessed by one-way ANOVA with Bonferroni post-test (for selected groups) or with Student's unpaired $t$ test; a value of $P<0.05$ was taken as being statistically significant.

\section{Results}

\section{Regulation of GPR120 and GPR84 gene expression}

In the first set of studies, the effect of a series of hormones and other factors on the expression of the GPR120 and GPR84 genes was examined in human adipocytes differentiated in culture from fibroblastic pre-adipocytes. The expression of the GPR41 gene was also explored. Both acute $(4 \mathrm{~h})$ and sustained $(24 \mathrm{~h})$ responses were examined, and a low and a high concentration of the agent were generally employed, based on previous work (Peeraully et al., 2004; Gao \& Bing, 
2011; Alomar et al., 2015). The initial studies focused on the effects of the pro-inflammatory cytokines TNF $\alpha$ and IL-1 $\beta$.

Incubation with TNF $\alpha$ resulted in a dose-dependent reduction in GPR120 mRNA level at both 4 and 24 h of treatment (Fig 1A). At 4 h, GPR120 mRNA level fell with the higher dose to $22 \%$ of the control cells, while at $24 \mathrm{~h}$ it was reduced to just $6 \%$ of controls - a 17 -fold reduction. In marked contrast to GPR120, there was a major stimulation of GPR84 expression by TNF $\alpha$ (Fig 1A), and as with GPR120 this was dose-dependent at both time-points. The increase in GPR84 mRNA was greater at 4 than at $24 \mathrm{~h}$, the level being $~ 200$-fold greater relative to the controls with the higher dose at $4 \mathrm{~h}$; surprisingly, the 46-fold increase in GPR84 mRNA at $24 \mathrm{~h}$ with the high dose was not statistically significant due to the considerable variation observed.

The effect of TNF $\alpha$ on the expression of GPR40, GPR41 and GPR43 was also determined. There was a marked stimulation of GPR41 expression at $24 \mathrm{~h}$, the mRNA level being $>30$-fold higher with both the low and high doses of the cytokine (Fig 1A). There was also an increase at 4 h, albeit much lower, at just 4-fold relative to the control cells (Fig 1A). Modest, but statistically significant, increases in GPR $40 \mathrm{mRNA}$ level at $4 \mathrm{~h}$ (both doses) and at $24 \mathrm{~h}$ for the low, though not the high, dose of TNF $\alpha$ were evident (results not shown). GPR43 mRNA level was not significantly increased by TNF $\alpha$ at $4 \mathrm{~h}$, but there was a significant increase at $24 \mathrm{~h}$ and this was greater for the low dose (11-fold) than the high (5-fold) (results not shown).

The effects of IL-1 $\beta$ were examined using a single high concentration, based on previous studies on human adipocytes with this cytokine (Alomar et al., 2015). IL-1 $\beta$ had broadly similar effects to TNF $\alpha$, with a reduction in GPR120 mRNA level and an increase in GPR84 mRNA (Fig 1B). However, the 2-fold decrease in GPR120 mRNA level in response to IL-1 $\beta$ was less than with TNF $\alpha$ and there was no difference between the 4 and $24 \mathrm{~h}$ time-points. The effect of IL-1 $\beta$ on GPR84 expression was dramatic with the mRNA level being $>500$-fold higher at $4 \mathrm{~h}$ compared with the control cells. This considerable effect of IL-1 $\beta$ was relatively transitory, with the increase in mRNA level falling sharply by $24 \mathrm{~h}$ to 15.7 -fold relative to the controls. There was also a marked stimulation of GPR41 expression in response to IL-1 $\beta$, the mRNA level being 16fold and 37-fold higher than in the control cells at 4 and $24 \mathrm{~h}$, respectively (Fig 1B).

Incubation with rosiglitazone led to a significant increase in GPR120 gene expression at both 4 and $24 \mathrm{~h}$ of treatment. With the highest dose of rosiglitazone, there was a nearly 8 -fold increase in GPR120 mRNA level at $24 \mathrm{~h}$ (Fig. 2A). GPR41 expression was also stimulated by rosiglitazone, paralleling the response of GPR120; the high dose of the PPAR $\gamma$ agonist resulted in a 10-fold increase in GPR41 mRNA level at $24 \mathrm{~h}$ (Fig. 2A). In contrast to GPR120 and GPR41, rosiglitazone had no effect on GPR84 expression (Fig. 2A). 
Insulin had no significant effect on GPR120 gene expression following $24 \mathrm{~h}$ of treatment, but there was a small stimulation with the higher dose at $4 \mathrm{~h}$, mRNA level being increased 4.7fold relative to the controls (Fig. 2B). There was no significant effect of insulin on either GPR84 (Fig 2B) or GPR41 expression (result not shown). Dexamethasone, with its anti-inflammatory action, was without effect on GPR120 mRNA level, irrespective of the dose or incubation time (Fig 2C). There was also no significant effect of the glucocorticoid on GPR84 mRNA, except at $24 \mathrm{~h}$ with the high dose where there was a small decrease (to $35 \%$ of the controls). There was also little effect of dexamethasone on GPR41 expression, except for a small though statistically significant, increase in mRNA level at $4 \mathrm{~h}$ with the higher dose (result not shown).

In the next set of experiments, the effects of two PUFAs were examined. The adipocytes were incubated with two different concentration of the fatty acids, as in the other studies. There was no significant effect of linoleic acid, an n-6 PUFA, on GPR120, GPR84 or GPR41 expression at either 4 or $24 \mathrm{~h}$ with both of the concentrations employed (Fig 3A). DHA, an n-3 PUFA which is a natural ligand for GPR120 (Milligan et al., 2015; Ulven \& Christiansen, 2015; Calder, 2016), also had no significant effect on GPR84 or GPR41 mRNA level at 4 or 24 h, and nor was there any effect on GPR120 mRNA level at $4 \mathrm{~h}$ (Fig 3B). There was, however, a small (2.2-fold), but statistically significant, increase at $24 \mathrm{~h}$ with the higher concentration of DHA (Fig 3B).

The final agent examined was TUG891, a synthetic agonist to GPR120 (Milligan et al., 2015; Gozal et al., 2016). Treatment with TUG891 had no significant effect on GPR120 gene expression, nor on the expression of GPR84 and GPR41; this was the case at 4 and $24 \mathrm{~h}$ of treatment and with both low and high doses of the agonist (Fig. 3C)

\section{Effect of TUG891 on the inflammatory response in adipocytes}

In view of the strong down-regulation of GPR120 expression by TNF $\alpha$ and IL-1 $\beta$, in the next studies the effect of GPR120 agonists on the inflammatory response evoked by these proinflammatory cytokines was examined. In the first experiment, adipocytes were treated with either TNF $\alpha$ or IL-1 $\beta$ in the presence and absence of TUG891 for $4 \mathrm{~h}$ to assess the effect of the agonist on the acute response to the pro-inflammatory cytokines. PCR arrays containing probes for 84 cytokine and chemokine genes were used to examine the response to $\mathrm{TNF} \alpha$ and whether this was attenuated by TUG891. The results in Table 1 indicate that TNF $\alpha$ had a powerful stimulatory effect on the expression of a substantial number of cytokine and chemokine genes (the full gene list is given in Appendix A). A total of 37 genes of those probed by the arrays exhibited increased expression (Appendix A); the mRNA level of 8 genes increased $>100$-fold with a further 10 exhibiting $>10$-fold increases (Table 1). The most strongly up-regulated genes were CXCL10, CCL5 and CCL1, the mRNA levels of which were 907-, 438- and 395-fold 
higher, respectively, than in the control untreated adipocytes. The expression of a small number of genes was inhibited by TNF $\alpha$, with IL11 and IL16 (8.8-fold reduction in mRNA level) being the most strongly down-regulated (Table 1).

In contrast to TNF $\alpha$, incubation with TUG891 had little effect on cytokine and chemokine expression (Table 1). IL15 was the only gene for which there was a statistically significant reduction in mRNA level (to $68 \%$ of control cells). There were, however, significant increases in mRNA for 19 genes, but for all but two of these the increase in level was just 1.1 to 2 -fold, with the highest (TNFSF11) being 3.5-fold. When the adipocytes were incubated with TNF $\alpha$ and TUG891 together, the changes in mRNA level relative to the untreated cells were very similar to those with TNF $\alpha$ alone, both in terms of the scale of change and the rank order of the responsive genes (Table 1). For example, as with TNF $\alpha$ on its own CXCL10 and CCL5 were the most strongly up-regulated genes with the combination of TNF $\alpha+$ TUG891, while IL16 was the most strongly down-regulated.

The impact of TUG891 on the response to TNF $\alpha$ is demonstrated most clearly by comparing mRNA levels in the TNF $\alpha+$ TUG891 group compared with TNF $\alpha$ alone. Table 1 shows that the presence of TUG891 led to a reduction in the mRNA level for only three genes, there being no significant change for $>70 \%$ of the genes probed by the arrays. The three genes where the TNF $\alpha$-stimulated expression was significantly inhibited by TUG891 were CXCL10, TGFB2 and TNFSF10, but in each case the decrease in the mRNA level was $<30 \%$; the fall in CXCL10 mRNA level in the presence of TUG891 was just 18\%. Paradoxically, rather than substantial decreases there was a statistically significant, albeit small, increase in mRNA level for 17 genes in the TUG891+TNF $\alpha$ group compared with TNF $\alpha$ alone; however, most of these changes resulted in increases of $<1.5$-fold with the highest (IL1RN) being 1.9-fold.

A similar study was conducted with adipocytes incubated with IL-1 $\beta$ in the presence and absence of TUG891, and in view of the results with TNF $\alpha$ the expression of selected genes was examined rather than multiple genes through PCR arrays. While treatment with IL-1 $\beta$ resulted in a substantial increase in CCL2, IL-1 $\beta$ and IL-6 mRNA levels, the addition of TUG891 did not attenuate the response (Fig 4). Similarly, the down-regulation of $A D I P O Q$ expression by IL-1 $\beta$ was not modified by TUG891. The presence of TUG891 also did not attenuate the increase in GPR84 expression stimulated by IL-1 $\beta$, but paradoxically it accentuated the reduction in GPR120 mRNA level induced by the cytokine (Fig $5 \mathrm{~A}$ ).

Analysis of selected inflammation-related adipokines in the medium showed that the presence of TUG891 did not alter the level of the secreted proteins evident with IL-1 $\beta$ alone; there was no difference between the IL-1 $\beta+$ TUG891 and IL-1 $\beta$ groups in the amounts of IL- 6 , 
IL-16, MCP-1 or adiponectin in the medium (Fig 6A). Similarly, with the adipocytes treated with TNF $\alpha$, the presence of TUG891 did not alter the quantity of MCP-1, IL-16 and adiponectin detected in the medium. In the case of $\mathrm{TNF} \alpha$ there was actually a small, but statistically significant, increase in the amount of this adipokine released by cells incubated with TUG891+TNF $\alpha$ relative to those with TNF $\alpha$ alone (Fig 6B).

\section{Effect of DHA on IL-1 $\beta$ induced changes in gene expression}

In the final experiment, adipocytes were incubated with DHA as a natural ligand to GPR120, and the inflammatory response induced by IL- $1 \beta$ examined in the presence and absence of the fatty acid. The adipocytes were incubated for 4 and $24 \mathrm{~h}$ in order to assess whether any putative effects are acute or chronic; results are, however, shown for $24 \mathrm{~h}$ only as no acute effects were evident.

The presence of DHA did not lead to an attenuation of the increases in IL- 6 and IL-1 $\beta$ mRNA level induced by IL-1 $\beta$ at either 4 or $24 \mathrm{~h}$ (Fig 7). There was, however, a significant attenuation of CCL2 gene expression at $24 \mathrm{~h}$ (Fig 7). Similarly, at $24 \mathrm{~h}$ the presence of DHA resulted in an attenuation in the decrease in IL16 and ADIPOQ expression observed with IL-1 $\beta$ (Fig 7). Thus, some modest effects of DHA on the inflammatory response induced by the proinflammatory cytokine are apparent. However, the presence of DHA did not have a protective effect on the reduction in GPR120 gene expression occurring with IL-1 $\beta$ (Fig 7). There was, in contrast, an attenuation by DHA of the IL-1ß-induced increase in GPR84 mRNA level (Fig 7).

As in the studies with TUG891, the effect of DHA on the release of key inflammationrelated adipokines from adipocytes treated with IL-1 $\beta$ was examined. The $24 \mathrm{~h}$ samples were used in order to assess the consequences of longer-term exposure to the fatty acid and the cytokine. The presence of DHA did not result in any changes in the amount of IL-6, IL-16, MCP-1 or adiponectin found in the medium (Fig 6C).

\section{Discussion}

The present study demonstrates that several factors influence the expression of the genes encoding the major fatty acid receptors/sensors - GPR120, GPR41 and GPR84 - in human adipocytes. Major responses were observed following exposure to pro-inflammatory mediators, while insulin, the glucocorticoid dexamethasone, and the fatty acids DHA and linoleic acid had no, or limited, effects. In a previous report it was noted that incubation of human adipocytes with macrophage-conditioned medium (from U937 cells) resulted in a substantial stimulation of GPR84 expression, while GPR120 expression was markedly inhibited (Trayhurn \& Denyer, 2012). A substantial up-regulation of GPR84 expression has also been observed in murine 3T3L1 adipocytes co-cultured with the RAW264 macrophage cell line (Nagasaki et al., 2012). 
Macrophage-conditioned medium contains a multiplicity of secretory products from the activated immune cells, among the most important of which are the cytokines TNF $\alpha$ and IL-1 $\beta$. GPR120 gene expression was inhibited in the present study by both these cytokines, the reduction in mRNA level being particularly marked with $\mathrm{TNF} \alpha$. In contrast, there was a major stimulation of GPR84, and to a lesser extent GPR41, expression by both TNF $\alpha$ and IL-1 $\beta$. Stimulation of GPR84 expression in 3T3-L1 and human adipocytes (adipose-derived stromal cells) by $\mathrm{TNF} \alpha$ has been observed previously, and also in response to lipopolysaccharide (Nagasaki et al., 2012). In the present study, the stimulatory effect on GPR84 expression was greatest with IL-1 $\beta$ at $4 \mathrm{~h}$, but there was no difference between IL-1 $\beta$ and TNF $\alpha$ in the peak effect on GPR41 expression. Differences in the time-course of the response of the two genes were apparent, however, with that of GPR 84 being greatest at $4 \mathrm{~h}$, with the mRNA level falling sharply by $24 \mathrm{~h}$; this effect was particularly evident with IL-1 $\beta$. In the case of GPR41, gene expression was more strongly stimulated at $24 \mathrm{~h}$, and this was most apparent with TNF $\alpha$.

Although a signal for GPR41 was consistently observed in the present work using real-time PCR, the mRNA was not detected in the study on macrophage-conditioned medium which utilised human Oligo microarrays (O’Hara et al., 2009). Studies on murine adipose tissue have also reported a lack of GPR41 expression (Zaibi et al., 2010), although some other reports have observed clear signals together with functional responses associated with this receptor (Xiong et al., 2004; Han et al., 2014). GPR41, for which the main ligands are short chain fatty acids (Milligan et al., 2014; Ulven \& Christiansen, 2015), is less well-characterised than the other GPCR fatty acid receptors, but it was reported to mediate the stimulation of leptin secretion from adipocytes by propionate and butyrate (Xiong et al., 2004). Subsequent studies have suggested, however, that this role is played by GPR43 rather than GPR41 (Zaibi et al., 2010).

The individual effects of IL-1 $\beta$ and TNF $\alpha$ suggest that these cytokines are key factors in the responses of human adipocytes to macrophage-conditioned medium (Trayhurn \& Denyer, 2012), although the involvement of other macrophage secretions cannot be excluded. The inflammatory response appears to be central to the overall regulation of the expression of GPCR fatty acid receptor genes, at least in adipocytes, and in the function of the encoded receptors. The up-regulation of GPR120 expression by rosiglitazone is also of note in this regard, given the antiinflammatory actions associated with the PPAR $\gamma$ receptor.

GPR84, the primary ligands for which are medium chain fatty acids of carbon chain length 9-14 (Wang et al., 2006), has been proposed as a pro-inflammatory receptor (Suzuki et al., 2013). For example, activation of GPR84 is reported to amplify the production of IL- 8 and IL-12 p40 by lipopolysaccharide in polymorphonuclear leukocytes as well as the production of TNF $\alpha$ in 
macrophages (Wang et al., 2006; Suzuki et al., 2013). On this basis, the stimulation of GPR84 synthesis in human adipocytes by cytokines, derived either from macrophages or from other adipocytes, would be predicted to result in an amplification of the inflammatory response in adipose tissue.

GPR120 has been the focus of considerable interest following the report that it is a receptor for $n-3$ PUFAs and mediates their anti-inflammatory and insulin-sensitising actions (Oh et al., 2010; Oh \& Olefsky, 2012). Medium-chain fatty acids are also ligands for this receptor. GPR120 has been implicated in energy balance, loss or dysfunction of the receptor leading to obesity in both mice and humans as well as to glucose intolerance and adipose tissue inflammation (Ichimura et al., 2012). Other functions in which the receptor is implicated include the promotion of GLP-1 secretion from gastrointestinal L- and K-cells, and the regulation of adipogenesis (Gotoh et al., 2007; Moniri, 2016). The proposed insulin-sensitising and antiinflammatory actions of GPR120 are of particular significance. GPR120 activation enhances glucose uptake and the translocation of GLUT4 in 3T3-L1 adipocytes, while in vivo studies have demonstrated that diets enriched in $n-3$ PUFAs lead to a reduction in macrophage infiltration in white adipose tissue of mice together with a reduction in the expression of pro-inflammatory genes such as IL1B, IL6 and CCL2, effects that are attenuated in GPR120 knockout mice (Oh et al., 2010).

As a consequence of its apparent regulatory function in inflammation and insulin sensitivity, GPR120 has been viewed as a therapeutic target in the treatment of insulin resistance, type 2 diabetes and the metabolic syndrome (Milligan et al., 2015; Ulven \& Christiansen, 2015). Natural ligands for the receptor include eicosapentanoic acid, pinolenic acid and DHA (Christiansen et al., 2015), while TUG891 and NCG21 are current examples of synthetic ligands (Hudson et al., 2013; Milligan et al., 2015; Ulven \& Christiansen, 2015). In view of the antiinflammatory action associated with GPR120 it appears paradoxical that macrophage secretions, and specifically IL-1 $\beta$ and TNF $\alpha$, lead to an inhibition of its synthesis. This is based on the marked inhibitory effects on gene expression; attempts to measure GPR120 protein in human adipocytes by Western blotting were unsuccessful (which may reflect low levels in the cells). A question of significance is whether the anti-inflammatory actions of $n-3$ PUFAs are compromised, or attenuated, by a loss in GPR120 receptor production under inflammatory conditions?

In the present study, the presence of TUG891 did not inhibit the acute stimulation of the expression of cytokine and chemokine genes induced by TNF $\alpha$, where PCR arrays were employed, or by IL-1 $\beta$ when selective genes were examined. The only gene whose expression was 
strongly stimulated by $\mathrm{TNF} \alpha$ and which exhibited an inhibitory response to the simultaneous presence of TUG891 was CXCL10, which encodes the interferon gamma-induced protein 10 (IP-10), and even this effect was modest. Thus, there was no evidence of a significant antiinflammatory effect of the GPR120 ligand in human adipocytes. Previous studies with TUG891 have indicated that it mimics the effects of GPR120 activation, such as the enhancement of glucose uptake by 3T3-L1 cells and inhibition of the release of pro-inflammatory mediators in macrophage cell lines (Hudson et al., 2013). In addition, TUG891 has recently been shown to significantly reduce inflammation and insulin resistance induced by chronic sleep fragmentation in mice (Gozal et al., 2016); the effects on inflammation were, however, based on macrophages present in the stromal-vascular fraction of white fat rather than the adipocyte component of the tissue.

DHA, a natural ligand for GPR120, did have some selective, though limited, effect on the response of human adipocytes to IL-1 $\beta$ with prolonged incubation. While DHA did not modify the IL-1 $\beta$ induced stimulation of IL6 and IL1B expression, there was a distinct attenuation of CCL2 expression, indicating that the production of a major chemoattractant (MCP-1) was reduced by the GPR120 ligand (in contrast to TUG891). Interestingly, a reversal of the fall in $A D I P O Q$ expression induced by IL-1 $\beta$ was also evident in the presence of DHA, implying that the $n$-3 PUFA aided the preservation of adiponectin synthesis. This would be consistent with the anti-inflammatory effect of DHA given that adiponectin itself has an anti-inflammatory (Ouchi et al., 1999; Yokota et al., 2000), as well as insulin-sensitising, action (Berg et al., 2001; Yamauchi et al., 2001). However, DHA did not alter the suppressive effect of IL-1 $\beta$ on the secretion of adiponectin into the medium, nor that of IL-6 and IL-16. The amount of these adipokines measured in the medium relates, of course, to the total released over the full $24 \mathrm{~h}$ incubation period, while the measurements of mRNA level reflect the situation pertaining at the $24 \mathrm{~h}$ timepoint itself.

The absence of a strong anti-inflammatory effect of both TUG891 and DHA in human adipocytes exposed to IL- $1 \beta$ and TNF $\alpha$ is not consistent with the proposition that $n-3$ PUFAs inhibit inflammation (Calder, 2011; Calder, 2015) and that GPR120 is a key receptor in mediating this action (Oh et al., 2010; Oh \& Olefsky, 2012). It is possible, of course, that human adipocytes are less responsive to both natural and synthetic GPR120 ligands than other cell types, particularly macrophages. If this is the case, then one potential explanation is that the amount of GPR120 is low in human adipocytes, and as noted above we were unable to successfully measure the protein in the human fat cells employed. 
An intriguing possibility is that the inflammatory response within human adipocytes is not significantly attenuated by DHA and other GPR120 receptor ligands since pro-inflammatory cytokines, as well as other macrophage- and adipocyte-derived factors, induce a substantial downregulation of the synthesis of this receptor. The presence of DHA did not prevent the inhibition of GPR120 gene expression induced by IL-1 $\beta$, so the apparent detrimental effects of an inflammatory stimulus on the production of the receptor are not ameliorated by the $n-3$ PUFA. Furthermore, the combination of TUG891 and IL-1 $\beta$ resulted in a greater down-regulation of GPR120 expression than with IL-1 $\beta$ alone. DHA (though not TUG891) did, however, attenuate the increase in GPR84 expression induced by IL-1 $\beta$, and since this receptor is considered proinflammatory (Suzuki et al., 2013) the $n$-3 PUFA did in effect exhibit some anti-inflammatory action.

\section{Conclusions}

The regulation of GPR120 and GPR84 expression in human adipocytes is strongly influenced by major pro-inflammatory cytokines, with an inhibition of the former and stimulation of the latter. In human fat cells, neither a natural nor a synthetic ligand of GPR120 was able to attenuate the major inflammatory response stimulated by $\mathrm{TNF} \alpha$ or IL-1 $\beta$, and this may in part be a consequence of an inflammation-induced reduction in the expression of the receptor. Adipocytes are able to exhibit a substantial inflammatory response (Rajala \& Scherer, 2003; Trayhurn \& Wood, 2004; Trayhurn, 2005), and despite this not being significantly attenuated by GPR120 agonists, $n$-3 PUFAs may have an overall anti-inflammatory action in adipose tissue through the other cell types within the tissue, especially the macrophages that are recruited in obesity.

\section{Declaration of interest}

We thank the Distinguished Scientist Fellowship Programme, King Saud University, for financial support of this work. LM is grateful to Professor Banni, University of Cagliari, for his support of her Training Fellowship at the University of Buckingham. We thank Professor Trond Ulven, University of Southern Denmark, for the provision of TUG891. The authors declare that they have no conflicts of interest with regard to this study.

\section{Appendix A. Supplementary data}

Supplementary data related to this article is attached. 


\section{References}

Alomar SY, Zaibi MS, Kępczyńska MA, et al. (2015). PCR array and protein array studies demonstrate that IL-1 $\beta$ (interleukin-1 $\beta$ ) stimulates the expression and secretion of multiple cytokines and chemokines in human adipocytes. Arch Physiol Biochem, 121:187-93.

Alomar SY, Gentili A, Zaibi MS, et al. (2016). IL-1 $\beta$ (interleukin-1 $\beta$ ) stimulates the production and release of multiple cytokines and chemokines by human preadipocytes. Arch Physiol Biochem, 122:117-22.

Berg AH, Combs TP, Du X, et al. (2001). The adipocyte-secreted protein Acrp30 enhances hepatic insulin action. Nat Med, 7:947-53.

Bluher M. (2009). Adipose tissue dysfunction in obesity. Exp Clin Endocrinol Diabetes, 117:241-50.

Calder PC. (2011). Fatty acids and inflammation: The cutting edge between food and pharma. Eur J Pharmacol, 668, Suppl 1:S50-S58.

Calder PC. (2015). Marine omega-3 fatty acids and inflammatory processes: effects, mechanisms and clinical relevance. Biochim Biophys Acta - Mol Cell Biol Lipids, 1851:469-84.

Calder PC. (2016). Docosahexaenoic Acid. Annal Nutr Metab, 69 (Suppl 1):7-21.

Christiansen E, Watterson KR, Stocker CJ, et al. (2015). Activity of dietary fatty acids on FFA1 and FFA4 and characterisation of pinolenic acid as a dual FFA1/FFA4 agonist with potential effect against metabolic diseases. BrJ Nutr, 113:1677-88.

Gao D, Bing C. (2011). Macrophage-induced expression and release of matrix metalloproteinase 1 and 3 by human preadipocytes is mediated by IL- $1 \beta$ via activation of MAPK signaling. $J$ Cell Physiol, 226:2869-80.

Gotoh C, Hong Y-H, Iga T, et al. (2007). The regulation of adipogenesis through GPR120. Biochem Biophys Res Commun, 354:591-97.

Gozal D, Qiao Z, Almendros I, et al. (2016). Treatment with TUG891, a free fatty acid receptor 4 agonist, restores adipose tissue metabolic dysfunction following chronic sleep fragmentation in mice. Int J Obes, 40:1143-49.

Han J-H, Kim I-S, Jung S-H, et al. (2014). The effects of propionate and valerate on insulin responsiveness for glucose uptake in 3T3-L1 adipocytes and C2C12 myotubes via G protein-coupled receptor 41. PLoS, 9:e95268.

Hasan AU, Ohmori K, Konishi K, et al. (2015). Eicosapentaenoic acid upregulates VEGF-A through both GPR120 and PPAR $\gamma$ mediated pathways in 3T3-L1 adipocytes. Mol Cell Endocrinol, 406:10-18.

Hotamisligil GS. (2006). Inflammation and metabolic disorders. Nature, 444:860-67. 
Hudson BD, Shimpukade B, Mackenzie AE, et al. (2013). The pharmacology of TUG-891, a potent and selective agonist of the free fatty acid receptor 4 (FFA4/GPR120), demonstrates both potential opportunity and possible challenges to therapeutic agonism. Mol Pharmacol, 84:710-25.

Ichimura A, Hirasawa A, Poulain-Godefroy O, et al. (2012). Dysfunction of lipid sensor GPR120 leads to obesity in both mouse and human. Nature, 483:350-4.

Itoh Y, Kawamata Y, Harada M, et al. (2003). Free fatty acids regulate insulin secretion from pancreatic $\beta$ cells through GPR40. Nature, 422:173-6.

Kępczyńska MA, Zaibi MS, Alomar SY, Trayhurn P. (2017). PCR arrays indicate that the expression of extracellular matrix and cell adhesion genes in human adipocytes is regulated by IL-1 $\beta$ (interleukin-1 $\beta$ ). Arch Physiol Biochem, 123:61-67.

Livak KJ, Schmittgen TD. (2001). Analysis of relative gene expression data using real-time quantitative PCR and the $2\left({ }^{\Delta \Delta} \mathrm{C}_{\mathrm{T}}\right)$ method. Methods, 25:402-8.

Milligan G, Ulven T, Murdoch H, Hudson BD. (2014). G-protein-coupled receptors for free fatty acids: nutritional and therapeutic targets. Br J Nutr, 111:S3-S7.

Milligan G, Alvarez-Curto E, Watterson KR, et al. (2015). Characterizing pharmacological ligands to study the long-chain fatty acid receptors GPR40/FFA1 and GPR120/FFA4. Br J Pharmacol, 172:3254-65.

Moniri NH. (2016). Free-fatty acid receptor-4 (GPR120): Cellular and molecular function and its role in metabolic disorders. Biochem Pharmacol, 110-111:1-15.

Nagasaki H, Kondo T, Fuchigami M, et al. (2012). Inflammatory changes in adipose tissue enhance expression of GPR84, a medium-chain fatty acid receptor: TNF $\alpha$ enhances GPR84 expression in adipocytes. FEBS Lett, 586:368-72.

O'Hara A, Lim F-L, Mazzatti D, Trayhurn P. (2009). Microarray analysis identifies matrix metalloproteinases (MMPs) as key genes whose expression is up-regulated in human adipocytes by macrophage-conditioned medium. Pflügers Archiv Eur J Physiol, 458:1103-14.

Oh DY, Talukdar S, Bae EJ, et al. (2010). GPR120 is an omega-3 fatty acid receptor mediating potent anti-inflammatory and insulin-sensitizing effects. Cell, 142:687-98.

Oh Da Y, Olefsky Jerrold M. (2012). Omega 3 fatty Acids and GPR120. Cell Metab, 15:564-65.

Ouchi N, Kihara S, Arita Y, et al. (1999). Novel modulator for endothelial adhesion molecules Adipocyte-derived plasma protein adiponectin. Circulation, 100:2473-76.

Peeraully MR, Jenkins JR, Trayhurn P. (2004). NGF gene expression and secretion in white adipose tissue: regulation in 3T3-L1 adipocytes by hormones and inflammatory cytokines. Am J Physiol Endocrinol Metab, 287:E331-39. 
Rajala MW, Scherer PE. (2003). The adipocyte - at the crossroads of energy homeostasis, inflammation, and atherosclerosis. Endocrinology, 144:3765-73.

Rosen ED, Spiegelman BM. (2006). Adipocytes as regulators of energy balance and glucose homeostasis. Nature, 444:847-53.

Song T, Zhou Y, Peng J, et al. (2016). GPR120 promotes adipogenesis through intracellular calcium and extracellular signal-regulated kinase 1/2 signal pathway. Mol Cell Endocrinol, 434:1-13.

Suzuki M, Takaishi S, Nagasaki M, et al. (2013). Medium-chain fatty acid-sensing receptor, GPR84, is a proinflammatory receptor. J Biol Chem, 288:10684-91.

Tolhurst G, Heffron H, Lam YS, et al. (2012). Short-chain fatty acids stimulate glucagon-like peptide-1 secretion via the G-protein-coupled receptor FFAR2. Diabetes, 61:364-71.

Trayhurn P, Wood IS. (2004). Adipokines: Inflammation and the pleiotropic role of white adipose tissue. BrJ Nutr, 92:347-55.

Trayhurn P. (2005). Endocrine and signalling role of adipose tissue: new perspectives on fat. Acta Physiol Scand, 184:285-93.

Trayhurn P, Denyer G. (2012). Mining microarray datasets in nutrition: expression of the GPR120 (n-3 fatty acid receptor/sensor) gene is down-regulated in human adipocytes by macrophage secretions. J Nutr Sci, 1:e3.

Ulven T, Christiansen E. (2015). Dietary fatty acids and their potential for controlling metabolic disease through activation of FFA4/GPR120. Ann Rev Nutr, 35:239-63.

Wang J, Wu X, Simonavicius N, et al. (2006). Medium-chain fatty acids as ligands for orphan G protein-coupled receptor GPR84. J Biol Chem, 281:34457-64.

Watterson KR, Hudson BD, Ulven T, Milligan G. (2014). Treatment of type 2 diabetes by free fatty acid receptor agonists. Front Endocrinol, 5:Article 137, 1-9.

Xiong Y, Miyamoto N, Shibata K, et al. (2004). Short-chain fatty acids stimulate leptin production in adipocytes through the G protein-coupled receptor GPR41. Proc Natl Acad Sci USA, 101:1045-50.

Yamauchi T, Kamon J, Waki H, et al. (2001). The fat-derived hormone adiponectin reverses insulin resistance associated with both lipoatrophy and obesity. Nat Med, 7:941-6.

Yokota T, Oritani K, Takahashi I, et al. (2000). Adiponectin, a new member of the family of soluble defense collagens, negatively regulates the growth of myelomonocytic progenitors and the functions of macrophages. Blood, 96:1723-32.

Zaibi MS, Stocker CJ, O'Dowd J, et al. (2010). Roles of GPR41 and GPR43 in leptin secretory responses of murine adipocytes to short chain fatty acids. FEBS Lett, 584:2381-86. 
Table 1. Effect of TNF $\alpha$ and the GPR120 agonist TUG891 on the expression of cytokine and chemokines genes in human adipocytes assessed by PCR arrays.

\begin{tabular}{|c|c|c|c|c|}
\hline Gene & $\begin{array}{l}\text { TNF } \alpha \text { cpd to } \\
\text { control } \\
\text { (fold-change) }\end{array}$ & $\begin{array}{l}\text { TUG891 cpd to } \\
\text { control } \\
\text { (fold-change) }\end{array}$ & $\begin{array}{l}\text { TNF } \alpha+\text { TUG891 cpd } \\
\text { to control (fold- } \\
\text { change) }\end{array}$ & $\begin{array}{c}\text { TNF } \alpha+\text { TUG891 } \\
\text { cpd to TNF } \alpha \text { (fold- } \\
\text { change) }\end{array}$ \\
\hline CXCL10 & $907^{* * *}$ & 0.285 & $747^{* * *}$ & $0.823 *$ \\
\hline CCL5 & $438 * * *$ & 0.968 & $461^{* * *}$ & 1.05 \\
\hline CCL1 & $395^{* * *}$ & 1.23 & $365^{* * *}$ & 0.922 \\
\hline CXCL11 & $305^{* * *}$ & 0.441 & $267^{* * *}$ & 0.875 \\
\hline CSF2 & $253^{* * *}$ & $2.47^{*}$ & $378^{* * *}$ & $1.49^{* * *}$ \\
\hline CCL3 & $207^{* * *}$ & 0.619 & $279 * * *$ & 1.35 \\
\hline CCL2O & $157^{* * *}$ & $1.92^{* * *}$ & $194^{* * *}$ & $1.24^{*}$ \\
\hline CX3CL1 & $140 * * *$ & 1.33 & $121^{* * *}$ & 0.863 \\
\hline CSF3 & $93.7^{* * *}$ & 1.66 & $135^{* * *}$ & $1.44 *$ \\
\hline CXCL8 & $89.2^{* * *}$ & $1.37^{* *}$ & $98.8^{* * *}$ & $1.11^{*}$ \\
\hline$T N F$ & $83.9^{* * *}$ & 0.695 & $69.3^{* * *}$ & 0.826 \\
\hline CCL19 & $59.6^{* * *}$ & 0.143 & $42.2^{* * *}$ & 0.708 \\
\hline IL1B & $55.9^{* * *}$ & 0.690 & $63.0^{* * *}$ & 1.13 \\
\hline CCL2 & $30.8^{* * *}$ & 1.13 & $31.9^{* * *}$ & 1.04 \\
\hline CXCL2 & $29.1^{* * *}$ & $1.41^{* * *}$ & $30.6^{* * *}$ & 1.05 \\
\hline CXCL1 & $25.3^{* * *}$ & $1.40 * *$ & $28.0^{* * *}$ & $1.11^{* *}$ \\
\hline CCL7 & $16.8^{* * *}$ & $1.73^{* * *}$ & $23.3^{* * *}$ & $1.39 * *$ \\
\hline IL6 & $11.0^{* * *}$ & $1.78^{* * *}$ & $14.9^{* * *}$ & $1.36^{* *}$ \\
\hline LIF & $8.62^{* * *}$ & $1.86^{* *}$ & $13.7^{* * *}$ & $1.59 * *$ \\
\hline BMP2 & $8.24^{* * *}$ & $2.31 * *$ & $14.7^{* * *}$ & $1.79 * *$ \\
\hline IL15 & $6.69^{* * *}$ & $0.682^{* *}$ & $6.74^{* * *}$ & 1.01 \\
\hline CXCL5 & $6.64^{* * *}$ & 1.02 & $8.09 * * *$ & $1.22^{* *}$ \\
\hline TNFRSF11B & $3.46^{* * *}$ & $1.39 * *$ & $3.78^{* * *}$ & 1.09 \\
\hline TNFSF11 & 3.41 & $3.54 *$ & 14.3 & 4.18 \\
\hline IL1RN & $3.14^{* * *}$ & $1.93 * *$ & $6.03^{* * *}$ & $1.92 * *$ \\
\hline TGFB2 & $2.37^{* * *}$ & 1.13 & $1.84^{* * *}$ & $0.779 * *$ \\
\hline TNFSF10 & $1.36^{* *}$ & 1.02 & 0.973 & $0.713^{* * *}$ \\
\hline TNFSF13B & $1.36^{* * *}$ & 0.985 & $1.22^{* *}$ & 0.896 \\
\hline IL12A & $0.806^{*}$ & $1.37^{* *}$ & 1.08 & $1.34^{* *}$ \\
\hline ADIPOQ & $0.729 *$ & 0.987 & 0.839 & 1.15 \\
\hline SPP1 & $0.675^{* * *}$ & 1.03 & $0.796 *$ & $1.18^{* *}$ \\
\hline BMP6 & $0.552^{* * *}$ & $1.23^{* *}$ & $0.696^{* * *}$ & $1.26^{*}$ \\
\hline IL11 & $0.226 *$ & $1.89 *$ & 0.670 & 2.97 \\
\hline IL16 & $0.113^{* * *}$ & 1.09 & $0.246^{* * *}$ & 2.18 \\
\hline
\end{tabular}

Differentiated human adipocytes were incubated in the presence or absence of human recombinant TNF $\alpha(100 \mathrm{ng} / \mathrm{ml})$, with and without TUG891 $(10 \mu \mathrm{M})$, for $4 \mathrm{~h}$. The expression of 84 cytokine and chemokine genes was probed using PCR pathway arrays. The results, which are for selected genes (the full gene list is given in Appendix A) are expressed as fold-changes in mRNA level for each treatment relative to the group to which it is compared, and are the means of 6 sets of adipocytes. ${ }^{*} P<0.05$, ${ }^{* *} P<0.01$, ***P $<0.001$ compared to control or to TNF $\alpha$ treated cells. All other differences are not statistically significant $(P>0.05)$. 


\section{Legends to Figures}

Figure 1. Effect of (A) TNF $\alpha$ and (B) IL-1 $\beta$ on the expression of the GPR120, GPR84 and GPR41 genes in human adipocytes. The adipocytes were incubated with TNF $\alpha$ or IL-1 $\beta$ for either 4 or $24 \mathrm{~h}$; LD, low dose TNF $\alpha(5 \mathrm{ng} / \mathrm{ml})$ and HD, high dose TNF $\alpha(100 \mathrm{ng} / \mathrm{ml})$. IL-1 $\beta$ was used at a concentration of $2 \mathrm{ng} / \mathrm{ml}$. The results, which are expressed as fold-changes in mRNA level in cells treated with $\mathrm{TNF} \alpha$ or IL-1 $\beta$ relative to the respective control cells, are means \pm SE (bars) for 4-6 sets of adipocytes. ${ }^{*} P<0.01$, $* * * P<0.001$ compared with the control cells (Con) at the same time point.

Figure 2. Effect of (A) rosiglitazone, (B) insulin and (C) dexamethasone on the expression of the GPR120 and GPR84 genes in human adipocytes. Data for GPR41 are also shown in the case of rosiglitazone. The adipocytes were incubated with rosiglitazone $(\mathrm{LD}$, low dose $=0.1 \mu \mathrm{M}$ and $\mathrm{HD}$, high dose $=1 \mu \mathrm{M})$, insulin $(\mathrm{LD}$, low dose $=1 \mathrm{nM}$; HD, high dose $=20 \mathrm{nM}$ ), or dexamethasone $(\mathrm{LD}$, low dose $=2 \mathrm{nM}$; HD, high dose $=20 \mathrm{nM}$ ) for either 4 or $24 \mathrm{~h}$ The results, which are expressed as fold-changes mRNA level in the cells treated with each agent relative to the respective control cells, are means \pm SE (bars) for $2-4$ sets of adipocytes. $* P<0.05$, $* * P<0.01$, $* * * P<0.001$ compared with the control cells (Con) at the same time point.

Figure 3. Effect of (A) linoleic acid, (B) docosahexaenoic acid and (C) TUG891 on the expression of the GPR120 and GPR84 genes in human adipocytes. The adipocytes were incubated with linoleic acid ( $\mathrm{LD}$, low dose $=50 \mu \mathrm{M}$; HD, high dose $=200 \mu \mathrm{M}$ ) or docosahexaenoic acid (LD, low dose $=25 \mu \mathrm{M}$; HD, high dose $=100 \mu \mathrm{M})$, or TUG891 (LD, low dose $=500 \mathrm{nM} ; \mathrm{HD}$, high dose $=10 \mu \mathrm{M}$ ) for either 4 or $24 \mathrm{~h}$. The results, which are expressed as fold-changes in mRNA level in the cells treated with the fatty acid or TUG891 relative to the control cells (Con), are means \pm SE (bars) for $2-4$ sets of adipocytes. $* P<0.05$ compared with the control cells at the same time point.

Figure 4. Effect of TUG891 on the changes induced by IL-1 $\beta$ in the expression of the CCL2, IL1B, IL6 and ADIPOQ genes in human adipocytes. The adipocytes were incubated with IL-1 $\beta$ $(0.5 \mathrm{ng} / \mathrm{ml})$, with and without TUG891 $(10 \mu \mathrm{M})$, for $4 \mathrm{~h}$. mRNA levels were measured by realtime PCR. The results, which are expressed as fold-changes in the mRNA level in treated cells relative to the control cells (Con), are means \pm SE (bars) for $4-6$ sets of adipocytes. ${ }^{* * *} P<0.001$ compared with the control cells. 
Figure 5. Effect of (A) TUG891 and (B) docosahexaenoic acid on the changes induced by IL-1 $\beta$ in the expression of the GPR120 and GPR84 genes in human adipocytes. The adipocytes were incubated with IL-1 $\beta(0.5 \mathrm{ng} / \mathrm{ml})$, with and without TUG891 $(10 \mu \mathrm{M})$ for $4 \mathrm{~h}$, or with and without docosahexaenoic acid $(100 \mu \mathrm{M})$, for $24 \mathrm{~h}$. The results, which are expressed as foldchanges in the treated cells relative to the control cells (Con), are means \pm SE (bars) for 4-6 sets of adipocytes. ${ }^{*} P<0.05,{ }^{*} P<0.01,{ }^{* * *} P<0.001$ compared with the control cells. ${ }^{\#} P<0.01$,

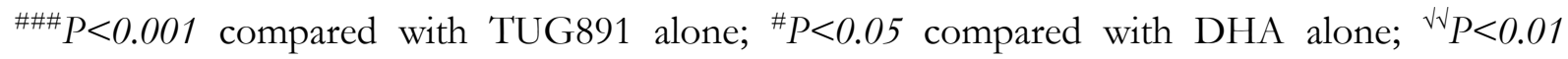
compared with IL-1 $\beta$ alone.

Figure 6. Release of inflammation-related adipokines from human adipocytes following treatment with either IL-1 $\beta$ or TNF $\alpha$ in the presence and absence of a GPR120 agonist. (A) IL$1 \beta(0.5 \mathrm{ng} / \mathrm{ml}) \pm$ TUG891 $(10 \mu \mathrm{M}),(\mathrm{B}) \mathrm{TNF} \alpha(100 \mathrm{ng} / \mathrm{ml}) \pm$ TUG891 $(10 \mu \mathrm{M})(\mathrm{C}) \mathrm{IL}-1 \beta \pm$ docosahexaenoic acid (DHA, $100 \mu \mathrm{M}$ ). The medium was from the adipocytes used in Figs 6, 7 and 9, and Table 1. The results are means \pm SE (bars) for 4 sets of adipocytes in each group; open bars, cytokine alone; filled bars cytokine + TUG891 or DHA. ${ }^{*} * * P<0.001$ compared with the cells incubated without TUG891 (open bars).

Figure 7. Effect of docosahexaenoic (DHA) acid on the changes induced by IL-1 $\beta$ in the expression of CCL2, IL1B, IL6 and $A D I P O Q)$ in human adipocytes. The adipocytes were incubated with IL-1 $\beta(0.5 \mathrm{ng} / \mathrm{ml})$, with and without DHA $(100 \mu \mathrm{M})$, for $24 \mathrm{~h}$. The results, which are expressed as fold-changes in mRNA level in treated cells relative to the control cells (Con), are means $\pm \mathrm{SE}$ (bars) for 6 sets of adipocytes. $* * * P<0.001$ compared with the control cells. ${ }^{\#} P<0.05,{ }^{\# \#} P<0.01,{ }^{\# \# \#} P<0.001$ compared with DHA alone. 
Figure 1

(A) TNF $\alpha$
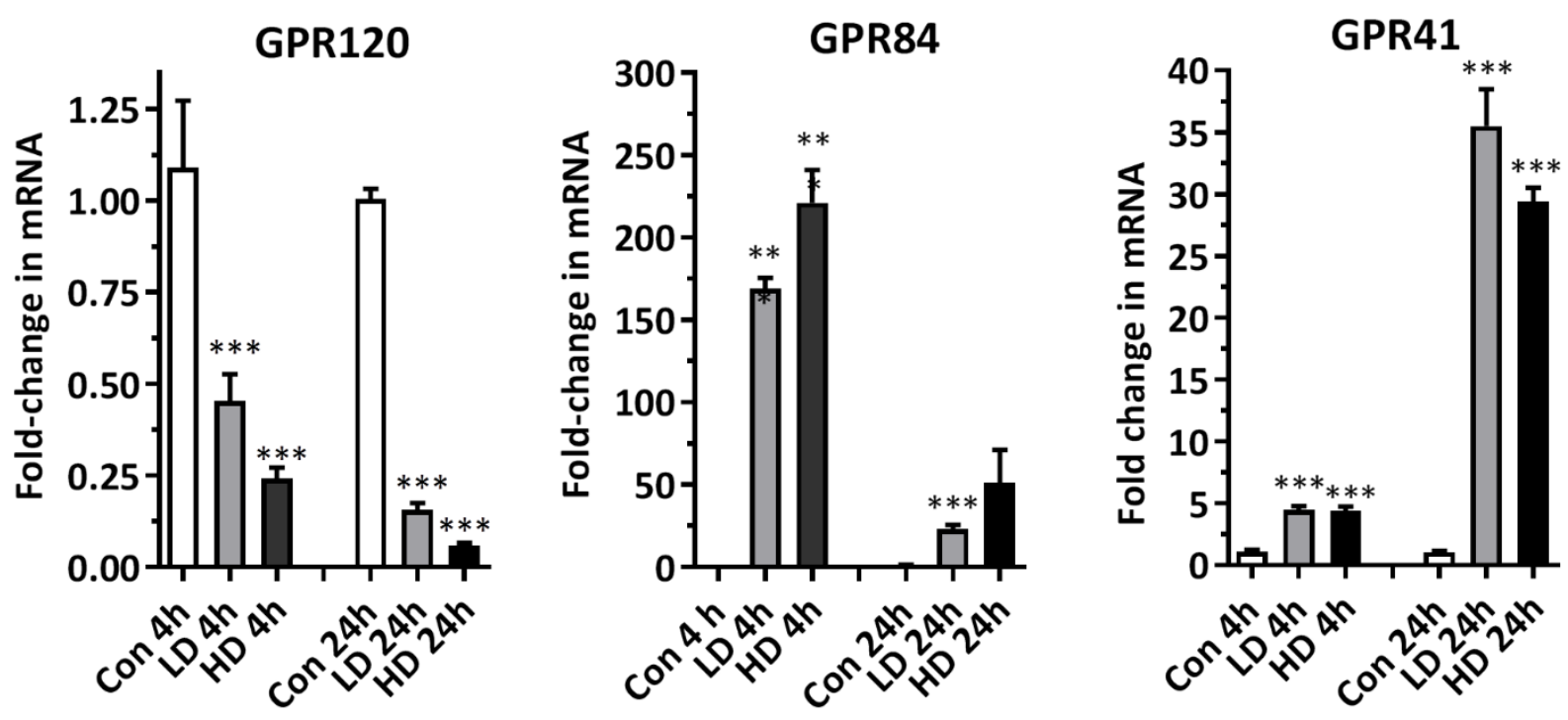

(B) IL-1 $\beta$
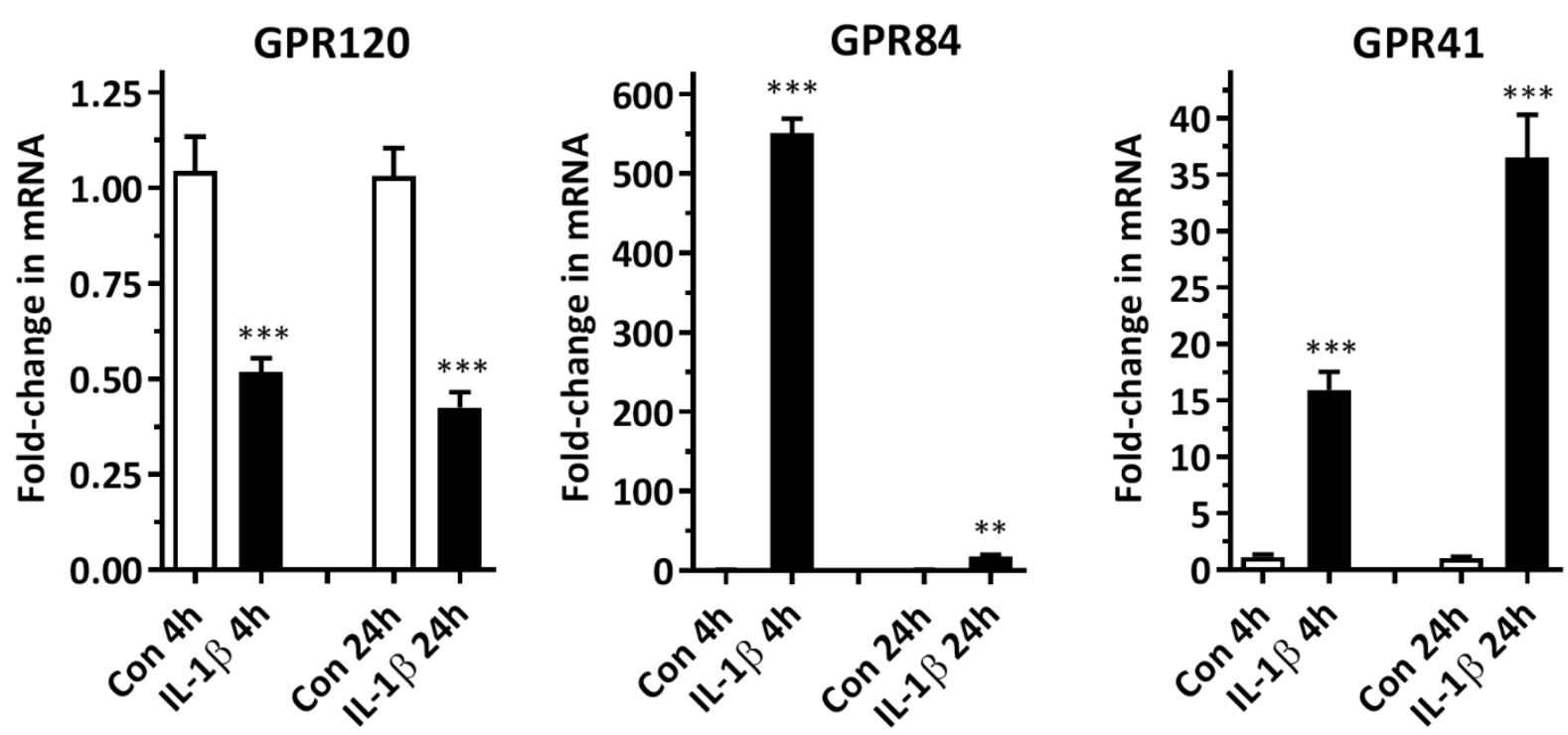
Figure 2

(A) Rosiglitazone
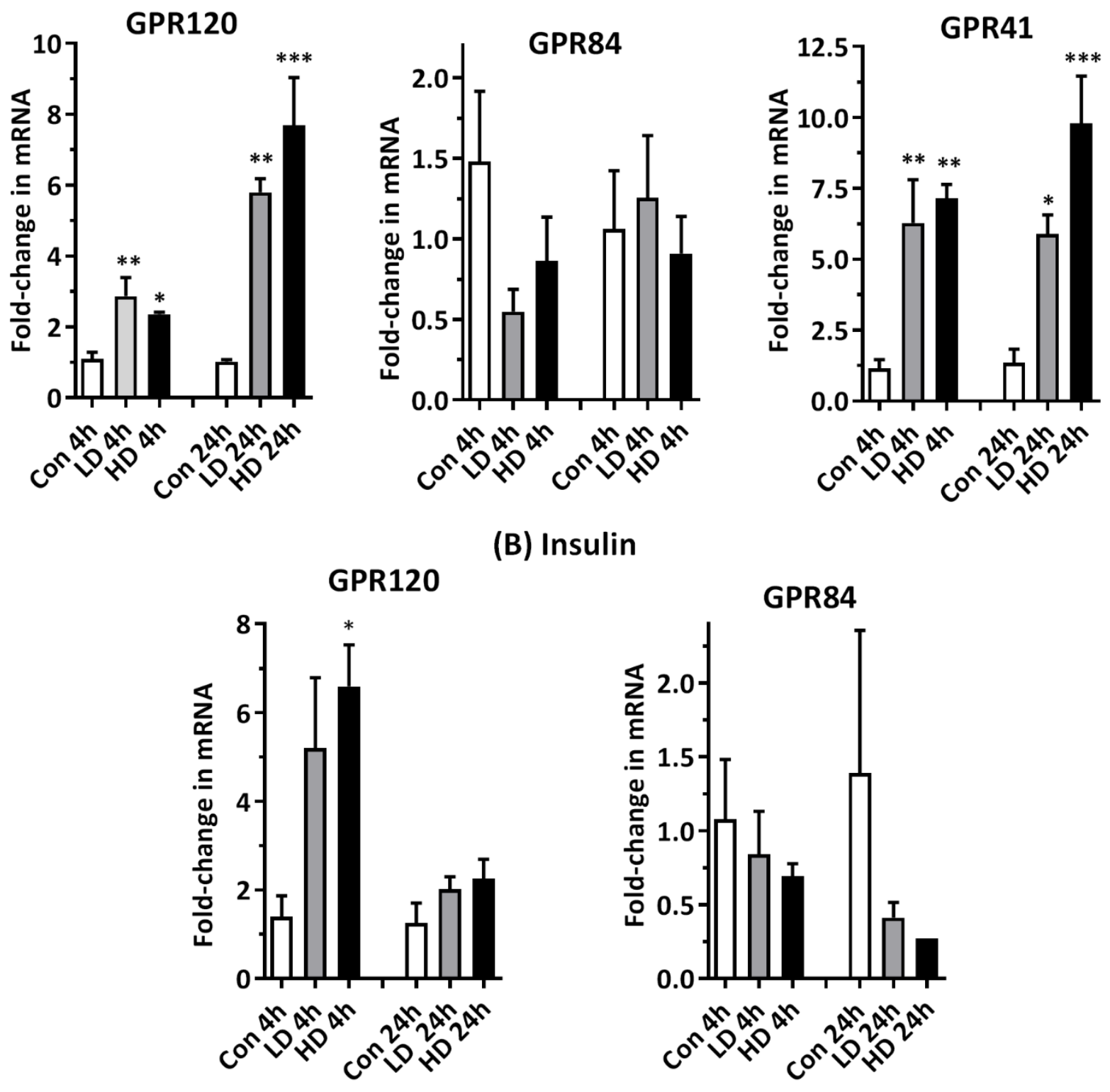

(B) Insulin

(C) Dexamethasone
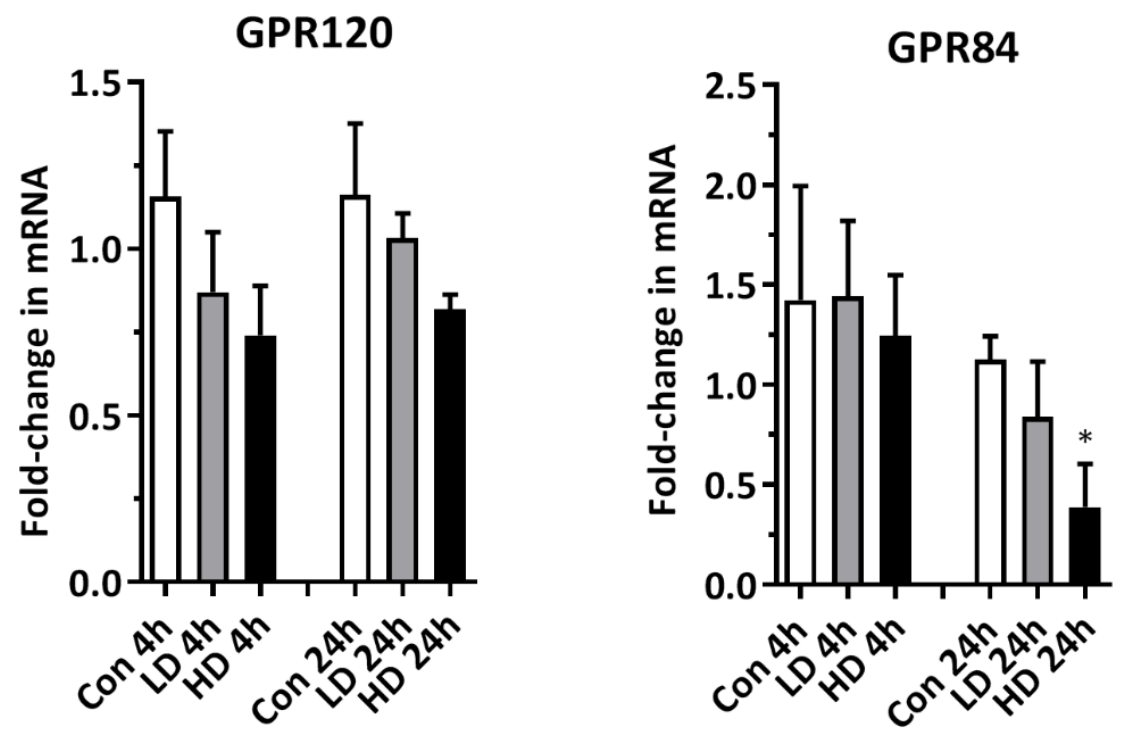
Figure 3

(A) Linoleic acid
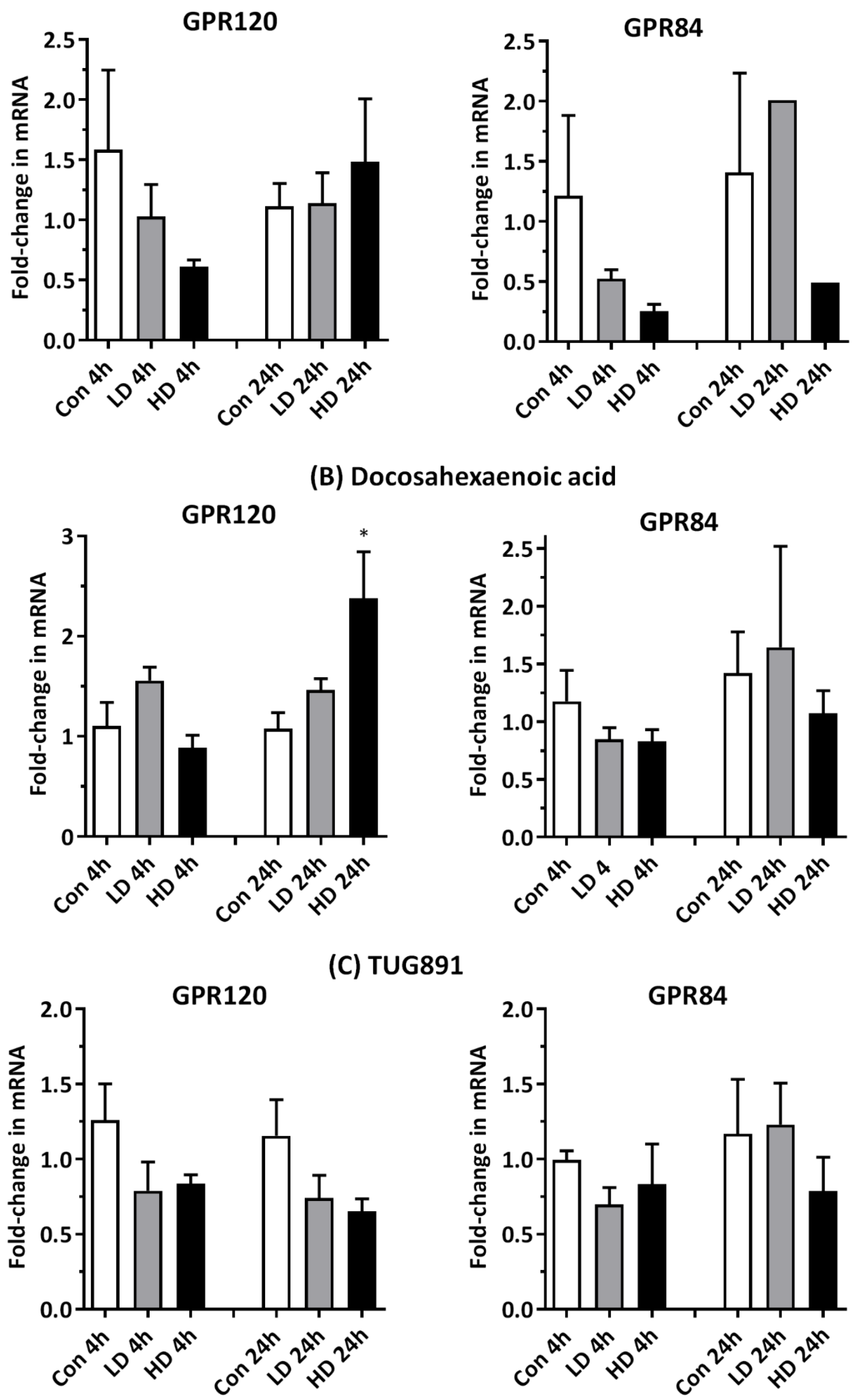
Figure 4
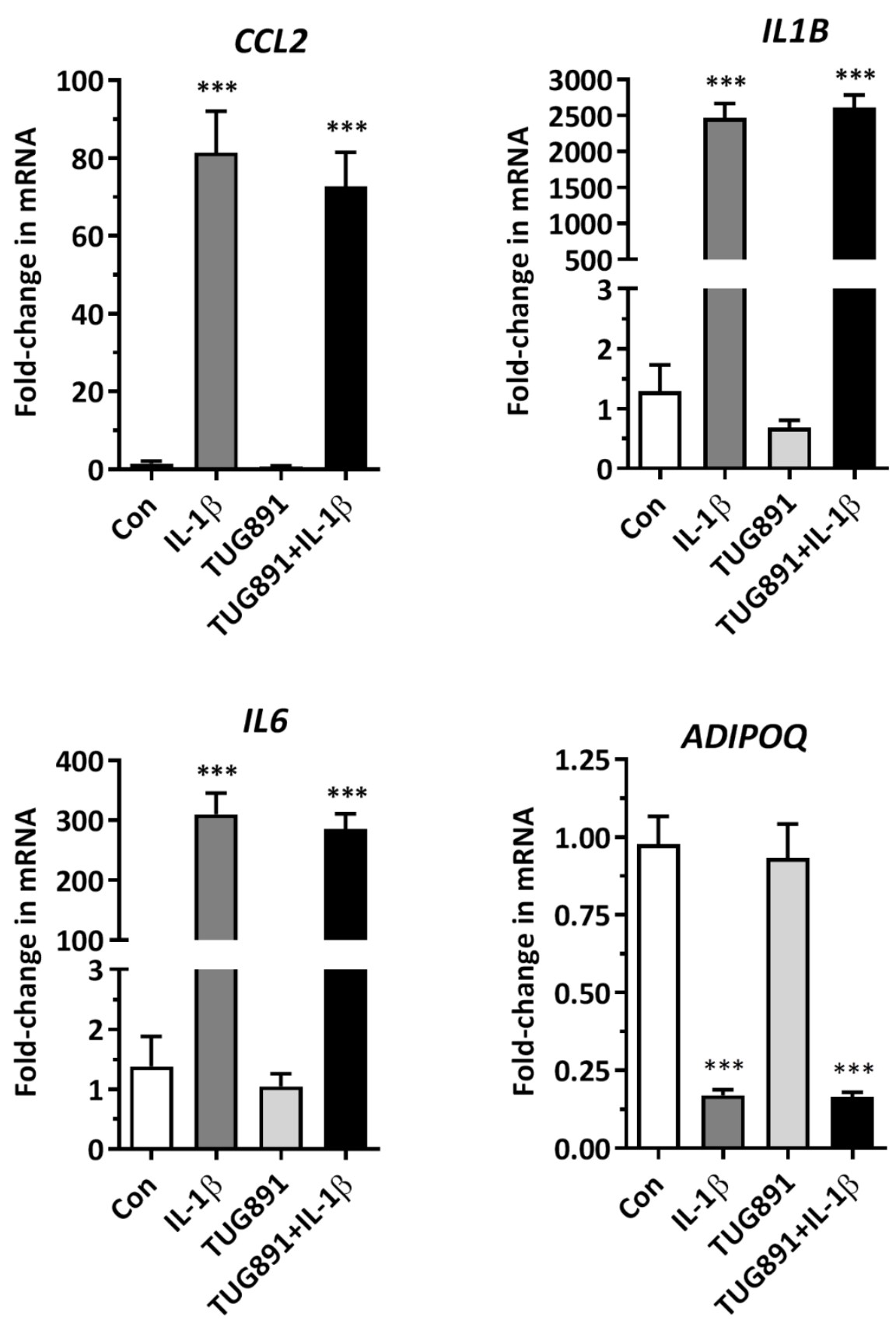
Figure 5

(A) TUG891 and IL-1ß

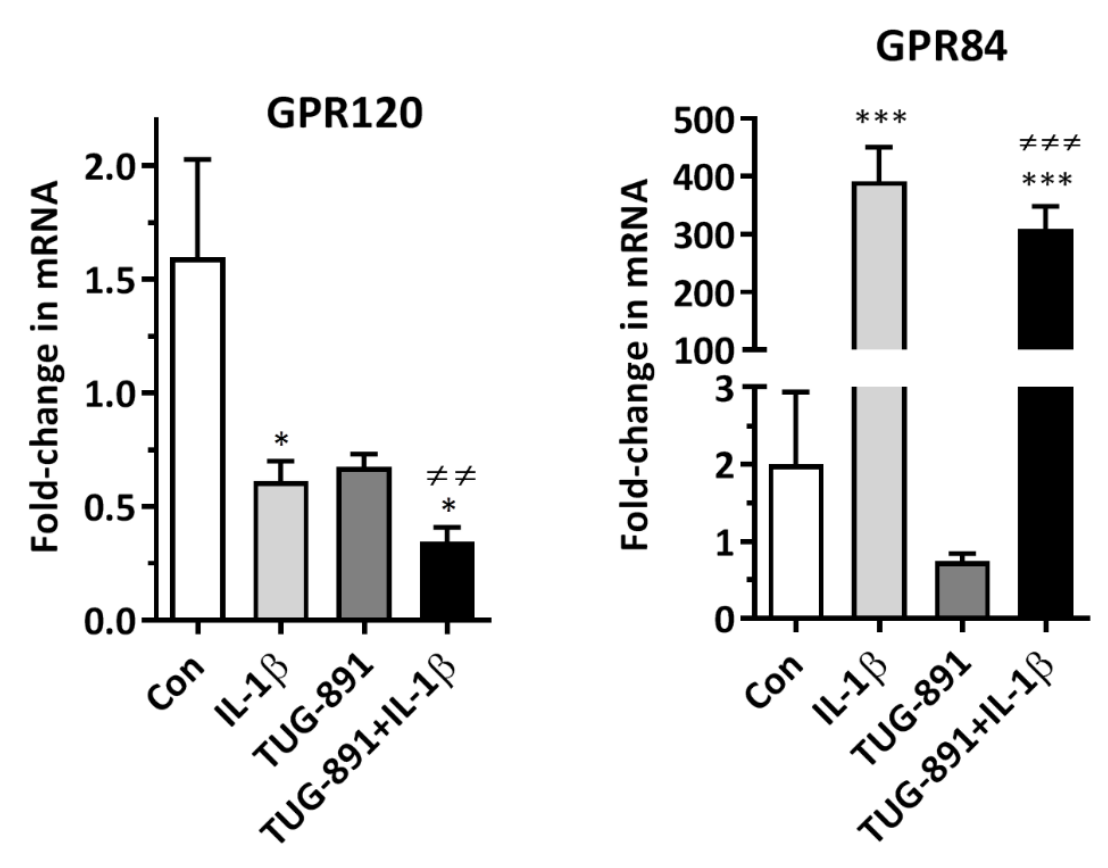

(B) DHA and IL-1 $\beta$
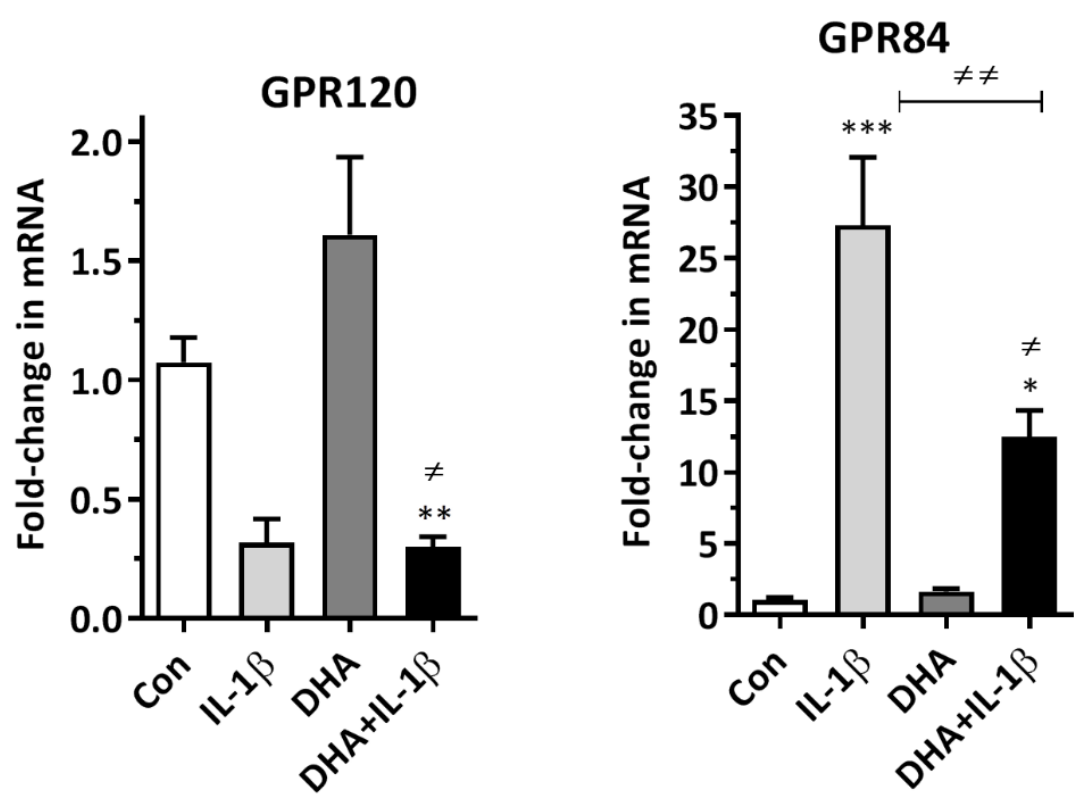
Figure 6

(A) IL-1 $\beta+$ TUG891

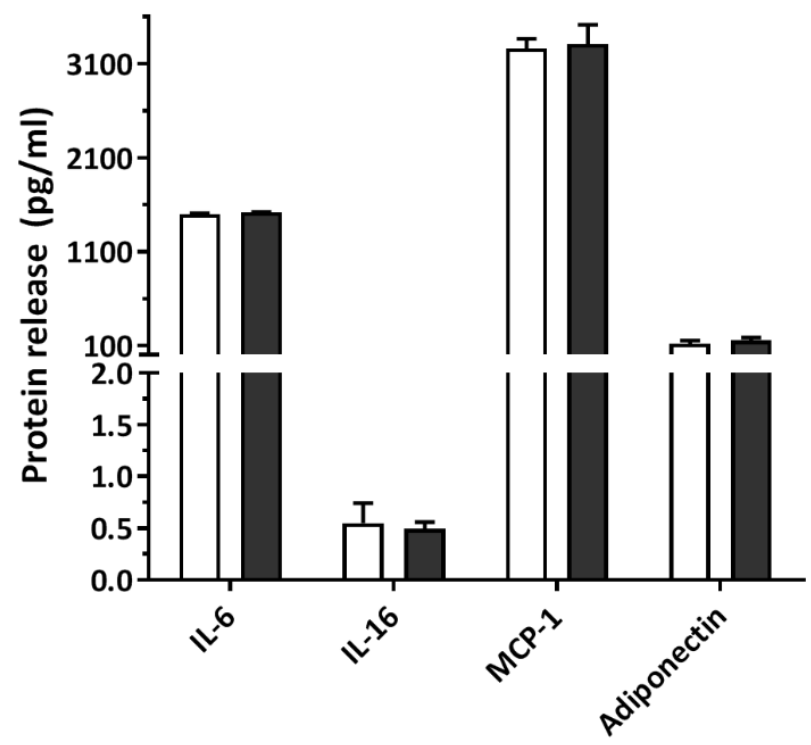

(B) TNF $\alpha+$ TUG891

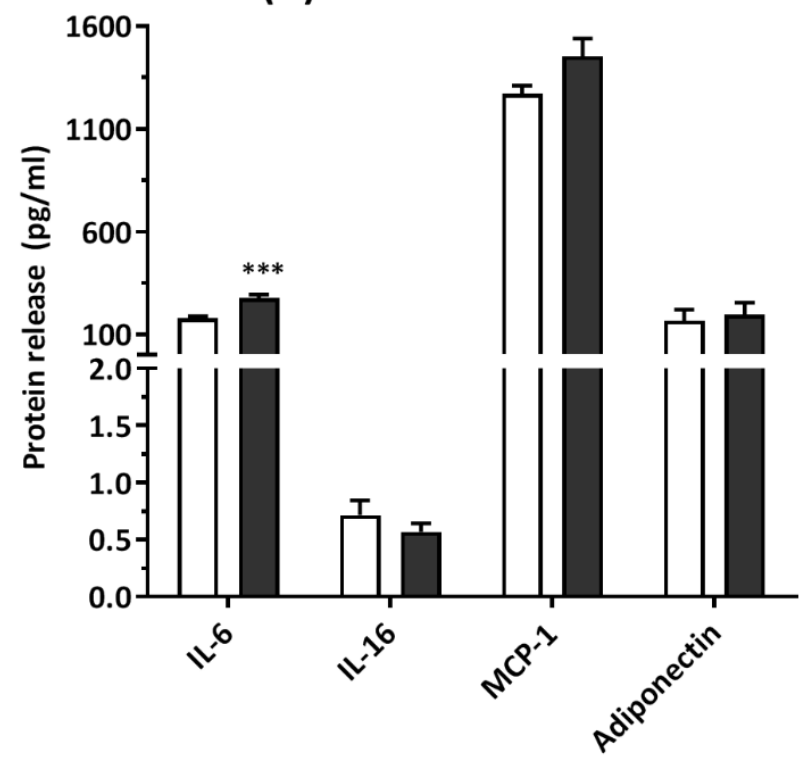

(C) IL-1 $\beta$ + DHA

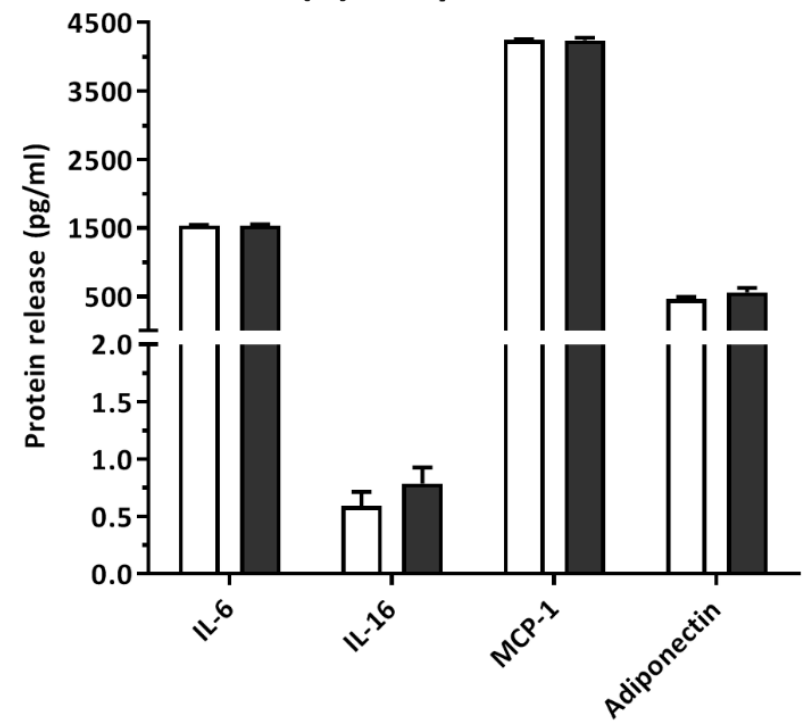


Figure 7
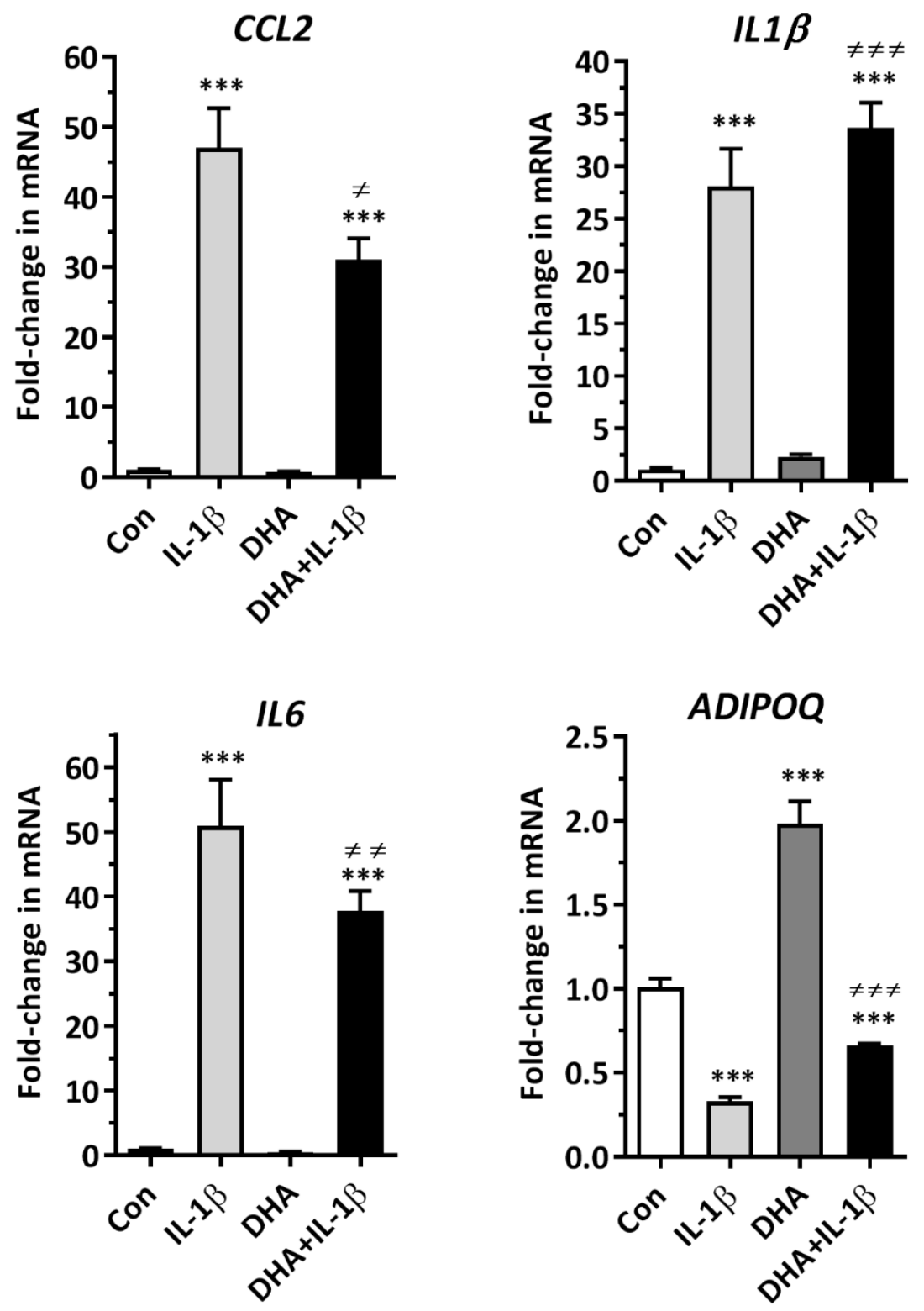
Appendix A

Supplement 1

Table 1. Effect of TNF $\alpha$ and the GPR120 agonist TUG891 on the expression of cytokine and chemokines genes in human adipocytes assessed by PCR arrays.

\begin{tabular}{|c|c|c|c|c|}
\hline Gene & $\begin{array}{c}\text { TNF } \alpha \text { cpd to } \\
\text { control } \\
\text { (fold-change) }\end{array}$ & $\begin{array}{l}\text { TUG891 cpd to } \\
\text { control } \\
\text { (fold-change) }\end{array}$ & $\begin{array}{l}\text { TNF } \alpha+\text { TUG891 cpd } \\
\text { to control (fold- } \\
\text { change) }\end{array}$ & $\begin{array}{c}\text { TNF } \alpha+\text { TUG891 } \\
\text { cpd to TNF } \alpha \\
\text { (fold-change) }\end{array}$ \\
\hline CXCL10 & $907^{* * *}$ & 0.285 & $747^{* * *}$ & $0.823 *$ \\
\hline CCL5 & $438^{* * *}$ & 0.968 & $461 * * *$ & 1.05 \\
\hline CCL1 & $395 * * *$ & 1.23 & $365^{* * *}$ & 0.922 \\
\hline CXCL11 & $305^{* * *}$ & 0.441 & $267^{* * *}$ & 0.875 \\
\hline CSF2 & $253^{* * *}$ & $2.47^{*}$ & $378^{* * *}$ & $1.49^{* * *}$ \\
\hline CCL3 & $207^{* * *}$ & 0.619 & $279 * * *$ & 1.35 \\
\hline CCL2O & $157^{* * *}$ & $1.92^{* * *}$ & $194^{* * *}$ & $1.24^{*}$ \\
\hline CX3CL1 & $140^{* * *}$ & 1.33 & $121^{* * *}$ & 0.863 \\
\hline CSF3 & $93.7^{* * *}$ & 1.66 & $135^{* * *}$ & $1.44^{*}$ \\
\hline CXCL8 & $89.2^{* * *}$ & $1.37^{* *}$ & $98.8^{* * *}$ & $1.11 *$ \\
\hline$T N F$ & $83.9 * * *$ & 0.695 & $69.3^{* * *}$ & 0.826 \\
\hline CCL19 & $59.6^{* * *}$ & 0.143 & $42.2^{* * *}$ & 0.708 \\
\hline IL1B & $55.9 * * *$ & 0.690 & $63.0^{* * *}$ & 1.13 \\
\hline CCL2 & $30.8^{* * *}$ & 1.13 & $31.9^{* * *}$ & 1.04 \\
\hline CXCL2 & $29.1^{* * *}$ & $1.41^{* * *}$ & $30.6^{* * *}$ & 1.05 \\
\hline CXCL1 & $25.3^{* * *}$ & $1.40 * *$ & $28.0^{* * *}$ & $1.11^{* *}$ \\
\hline CCL7 & $16.8^{* * *}$ & $1.73^{* * *}$ & $23.3^{* * *}$ & $1.39 * *$ \\
\hline IL6 & $11.0^{* * *}$ & $1.78^{* * *}$ & $14.9^{* * *}$ & $1.36^{* *}$ \\
\hline CCL11 & $9.63^{* * *}$ & 0.321 & $9.44 * *$ & 0.981 \\
\hline LIF & $8.62^{* * *}$ & $1.86^{* *}$ & $13.7^{* * *}$ & $1.59 * *$ \\
\hline BMP2 & $8.24^{* * *}$ & $2.31^{* *}$ & $14.7^{* * *}$ & $1.79 * *$ \\
\hline IL15 & $6.69^{* * *}$ & $0.682^{* *}$ & $6.74^{* * *}$ & 1.01 \\
\hline CXCL5 & $6.64^{* * *}$ & 1.02 & $8.09 * * *$ & $1.22^{* *}$ \\
\hline CXCL9 & $6.46^{*}$ & 1.03 & 3.40 & 0.527 \\
\hline CSF1 & $4.84^{* * *}$ & $1.09 * *$ & $4.87^{* * *}$ & 1.01 \\
\hline LTB & $3.91 *$ & 0.960 & 2.28 & 0.583 \\
\hline TNFRSF11B & $3.46^{* * *}$ & $1.39 * *$ & $3.78^{* * *}$ & 1.09 \\
\hline TNFSF11 & 3.41 & $3.54^{*}$ & 14.3 & 4.18 \\
\hline IL1RN & $3.14^{* * *}$ & $1.93^{* *}$ & $6.03^{* * *}$ & $1.92 * *$ \\
\hline TGFB2 & $2.37^{* * *}$ & 1.13 & $1.84^{* * *}$ & $0.779^{* *}$ \\
\hline IL23A & $2.01^{* * *}$ & $1.82^{*}$ & $2.11^{* *}$ & 1.05 \\
\hline IL5 & 1.90 & 1.14 & 0.237 & 0.124 \\
\hline CCL13 & $1.47^{* * *}$ & 0.958 & $1.79^{* * *}$ & $1.22^{*}$ \\
\hline CNTF & $1.37^{* * *}$ & 1.21 & $1.52^{* * *}$ & 1.11 \\
\hline BMP4 & 1.37 & 1.14 & $1.82^{*}$ & 1.33 \\
\hline TNFSF10 & $1.36^{* *}$ & 1.02 & 0.973 & $0.713^{* * *}$ \\
\hline VEGFA & $1.36^{* *}$ & $1.29 * *$ & $1.68^{* * *}$ & $1.23^{* *}$ \\
\hline TNFSF13B & $1.36^{* * *}$ & 0.985 & $1.22^{* *}$ & 0.896 \\
\hline IL7 & $1.36^{* * *}$ & 0.849 & $1.43^{* * *}$ & 1.05 \\
\hline PPBP & 1.35 & 1.16 & 1.10 & 0.817 \\
\hline CXCL16 & $1.31^{*}$ & 1.22 & $1.24 *$ & 0.951 \\
\hline
\end{tabular}




\begin{tabular}{|lcccc|}
\hline LTA & 1.19 & 1.12 & $3.31^{*}$ & 2.79 \\
IL18 & 1.08 & 0.837 & 1.12 & 1.04 \\
MIF & 1.01 & $1.07^{* *}$ & 0.960 & 0.946 \\
CXCL12 & 1.00 & 1.04 & 1.07 & 1.06 \\
GPI & $0.964^{*}$ & 1.02 & 0.990 & 1.03 \\
CCL21 & 0.842 & 1.37 & 2.25 & 2.68 \\
C5 & $0.825^{*}$ & 0.886 & $0.770^{* *}$ & 0.933 \\
IL27 & 0.808 & 1.68 & 1.58 & 1.95 \\
IL12A & $0.806^{*}$ & $1.37^{* *}$ & 1.08 & $1.34^{* *}$ \\
NODAL & 0.797 & 1.49 & 1.19 & 1.49 \\
IL13 & 0.754 & 2.39 & 1.41 & 1.87 \\
ADIPOQ & $0.729 *$ & 0.987 & 0.839 & 1.15 \\
MSTN & 0.701 & 0.939 & 0.729 & 1.04 \\
IL22 & $0.699^{*}$ & 0.995 & 1.24 & 1.77 \\
SPP1 & $0.675^{* * *}$ & 1.03 & $0.796^{*}$ & $1.18^{* *}$ \\
THPO & 0.658 & 1.21 & 0.999 & $1.52^{*}$ \\
IL4 & 0.656 & 0.919 & 1.59 & 2.42 \\
IL21 & 0.643 & $N D$ & 0.790 & 1.23 \\
BMP6 & $0.552^{* * *}$ & $1.23^{* *}$ & $0.696 * * *$ & $1.26^{*}$ \\
IL24 & 0.515 & 0.715 & 0.553 & 1.08 \\
IL17F & 0.445 & 0.554 & 1.08 & 2.42 \\
BMP7 & 0.432 & 0.394 & 0.630 & 1.46 \\
CCL18 & $0.419^{*}$ & 0.696 & 0.743 & 1.77 \\
IFNA2 & 0.405 & 0.606 & 1.35 & 3.32 \\
CD4OLG & 0.370 & 0.880 & 0.298 & 0.805 \\
IL11 & $0.226 *$ & $1.89 *$ & 0.670 & 2.97 \\
IL16 & $0.113^{* * *}$ & 1.09 & $0.246^{* * *}$ & 2.18 \\
\hline
\end{tabular}

Differentiated human adipocytes were incubated in the presence or absence of human recombinant TNF $\alpha(100 \mathrm{ng} / \mathrm{ml})$, with and without TUG891 $(10 \mu \mathrm{M})$, for $4 \mathrm{~h}$. The expression of 84 cytokine and chemokine genes was probed using PCR pathway arrays. The results are expressed as fold-changes in mRNA level for each treatment relative to the group to which it is compared, and are the means of 6 sets of adipocytes. ${ }^{*} P<0.05$, **P $<0.01$, ${ }^{*} * P<0.001$ compared to control or to TNF $\alpha$ treated cells. All other differences are not statistically significant $(P>0.05)$. 


\section{Annex: Acceptance Information}

$01-$ Aug -2017

Dear Professor Trayhurn:

Ref: IL-1 $\beta$ and TNF $\alpha$ inhibit GPR120 (<i>FFAR4</i>) and stimulate GPR84 $(<i>$ EX33</i>) and GPR41 (<i>FFAR3</i>) fatty acid receptor expression in human adipocytes: implications for the anti-inflammatory action of $n-3$ fatty acids

Our referees have now considered your paper and have recommended publication in Archives of Physiology And Biochemistry. We are pleased to accept your paper in its current form which will now be forwarded to the publisher for copy editing and typesetting. The reviewer comments are included at the bottom of this letter.

You will receive proofs for checking, and instructions for transfer of copyright in due course.

The publisher also requests that proofs are checked and returned within 48 hours of receipt.

Thank you for your contribution to Archives of Physiology And Biochemistry and we look forward to receiving further submissions from you.

Sincerely,

Dr Eckel

Editor in Chief, Archives of Physiology And Biochemistry

eckel@uni-duesseldorf.de 